\title{
Natural and semisynthetic candidate molecules for COVID-19 prophylaxis and treatment
}

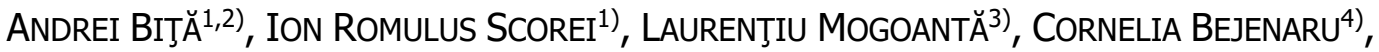 \\ GEORGE DAN MOgoŞANU'2), LUDOVIC EVERARD BEJENARU²) \\ 1) BioBoron Research Institute, S.C. Natural Research S.R.L., Podari, Dolj County, Romania \\ 2) Department of Pharmacognosy \& Phytotherapy, Faculty of Pharmacy, University of Medicine and Pharmacy of Craiova, \\ Romania \\ 3) Research Center for Microscopic Morphology and Immunology, University of Medicine and Pharmacy of Craiova, Romania \\ 4) Department of Pharmaceutical Botany, Faculty of Pharmacy, University of Medicine and Pharmacy of Craiova, Romania
}

\begin{abstract}
Coronaviruses (CoVs) represent a family of viruses that have numerous animal hosts, and they cause severe respiratory, as well as systemic and enteric infections, in humans. Currently, there are limited antiviral strategies for treating patients infected with severe acute respiratory syndrome coronavirus 2 (SARS-CoV-2). The lack of specific antiviral medicines and SARS-CoV-2 vaccines continues to aggravate the situation. Natural product-based antiviral drugs have been used in the two previous CoV outbreaks: Middle East respiratory syndrome coronavirus (MERS-CoV) and the first SARS-CoV. This review emphasizes the role of natural and semisynthetic candidate molecules for coronavirus disease 2019 (COVID-19) prophylaxis and treatment. The experimental evidence suggests that nature could offer huge possibilities for treatment of the COVID-19 pandemic.
\end{abstract}

Keywords: COVID-19, hydroxychloroquine, azithromycin, hesperidin, rosocyanin.

\section{Background}

\section{Coronaviruses}

Coronaviruses (CoVs) represent a family of viruses that have numerous animal hosts (cattle, pigs, cats, horses, dogs, camels, bats, rodents, ferrets, palm civets, mumps, rabbits, snakes, and avian species) that cause severe respiratory infections in humans, as well as systemic and enteric infections. The CoVs family consists of four main groups $[1,2]$ :

(i) Alpha-CoVs, which infect bats, pigs, cats, dogs, and humans (causing rhinopharyngitis).

(ii) Beta-CoVs, which mainly circulate in bats, but can also affect cattle, horses, pigs, dogs, mice, rats, hedgehogs, and other mammals. Two species cause rhinopharyngitis in humans: human HKU1 and OC43 CoVs. Two other species cause very severe respiratory syndromes in humans: Middle East respiratory syndrome coronavirus (MERS$\mathrm{CoV}$ ) and the first severe acute respiratory syndrome coronavirus (SARS-CoV) in Asia. Recently, at the end of December 2019, SARS-CoV-2 (a new coronavirus) was identified in Wuhan, China, which is highly infectious, easily transmitted from human to human and it causes severe pneumonia.

(iii) Gamma-CoVs are mainly avian viruses, but they also infect dolphins.

(iv) Delta-CoVs are mainly avian viruses but can also infect pigs.

Two potentially dangerous zoonotic CoVs have emerged over the past two decades: SARS-CoV, originating in China (Guangdong Province), that caused an outbreak from 2002 to 2003, and MERS-CoV, which caused an outbreak in 2012. Like most CoVs in the beta group, the hosts of MERS-CoV, SARS-CoV and SARS-CoV-2 are bats, probably the natural reservoir of these viruses; infected dromedaries are only intermediate hosts of MERS-CoV, and palm civets are intermediate hosts for SARS-CoV. There have been many attempts to identify the intermediate host for SARS-CoV-2, yet it has still not been detected [3-5]. Currently, no specific antiviral drugs or vaccines have been approved to combat SARS and MERS. In order to stop the SARS pandemic in 2002-2003, several restrictions on travel and patients' isolation were applied, as well as measures of conventional control $[1,6]$.

\section{The new SARS-CoV-2 coronavirus}

\section{Official name}

The International Committee on Taxonomy of Viruses (ICTV) stated that the new virus is named SARS-CoV-2 (February $\left.11^{\text {th }}, 2020\right)$. At the same time, the World Health Organization (WHO) announced that the name of the new disease caused by SARS-CoV-2 is coronavirus disease 2019 (COVID-19), and subsequently, on March $11^{\text {th }}, 2020$, WHO declared a pandemic for SARS-CoV-2 [7, 8].

\section{Mechanism of action}

SARS-CoV-2 encodes 29 proteins; four make up the virus's actual structure, including the spike ('S') protein. One group of the remaining 25 coronavirus proteins coordinates how the virus assembles copies of itself and how it sneaks past the host's immune system [9]. SARS-CoV-2 has the following structural proteins: ' $\mathrm{S}$ ' glycoprotein, which causes the virus to attach to the membranes of human host cells; 'E' glycoprotein, which

This is an open-access article distributed under the terms of a Creative Commons Attribution-NonCommercial-ShareAlike 4.0 International Public License, which permits unrestricted use, adaptation, distribution and reproduction in any medium, non-commercially, provided the new creations are licensed under identical terms as the original work and the original work is properly cited. 
is required for the initial uptake of the virus by the host cell membranes; ' $M$ ' protein of the viral membrane, playing a role in viral assembly; and ' $N$ ' protein of the nucleocapsid, involved in the regulation of viral ribonucleic acid (RNA) synthesis [7, 8, 10, 11].

Until recently, SARS-CoV-2 infection was thought to only occur through binding to a widespread human cell receptor, angiotensin-converting enzyme 2 (ACE2) [12]. Thus, the human cells are infected with SARS-CoV-2 by the binding of the surface ' $S$ ' glycoprotein to the human ACE2, the main host cell receptor for the virus. However, the existence of only one virus entry receptor was not sufficient to explain the high infectivity and severity of COVID-19 disease. Recent research has shown that another human host cell receptor, the extracellular matrix metalloproteinase [cluster of differentiation 147 (CD147)] inducer, also known as basigin (BSG) or extracellular matrix metalloproteinase inducer (EMMPRIN), makes an important contribution to "opening the door" for SARS-CoV-2 infection [13]. Recent evidence suggests that SARS-CoV-2 may be using a co-receptor when entering the cells, the same one used by MERS-CoV, namely the dipeptidyl peptidase-4 (DPP-4)/CD26 receptor. New studies have shown that SARS-CoV-2 binds to DPP4/CD26 when entering the cells of the respiratory tract [14-16]. Probably, there are other receptors, still undiscovered, which will have major significance in the fight against COVID-19 [17].

SARS-CoV-2 is 1000 times more aggressive than SARS-CoV, having a "double attack" approach, by binding to the human cell membrane, using both a host cell enzyme (furin) and ACE2 as receptors. Early indications are that SARS-CoV-2 also requires ACE2 and transmembrane protease serine 2 (TMPRSS2) to enter cells [18]. As a result of the "double attack", the ' $\mathrm{S}$ ' glycoprotein from SARS-CoV-2 has significantly less free energy than SARS$\mathrm{CoV}$, which suggests that, at the same temperature, SARSCoV-2 is more stable and has a capacity of infection greater than SARS-CoV. Moreover, SARS-CoV-2 may survive high temperatures, becoming infectious when temperatures are low (during wintertime). This did not happen with SARS-CoV, which, after 2003, did not withstand high temperatures and disappeared [19].

\section{Epidemiology, prevention, and control of SARS-CoV-2}

Respiratory CoVs are likely to spread in a manner similar to that of rhinoviruses, through direct contact with an infected person, infected secretions, with large aerosol drops or even through fecal-oral transmission. COVID-19 is transmitted from symptomatic persons to other persons to which they are in close contact by respiratory drops, by direct contact with infected persons or by contact with contaminated objects or surfaces. COVID-19 is more pronounced in the upper respiratory tract (nose and throat) earlier, meaning during the first three days following the symptoms' debut. It is not yet clear whether the virus can spread before the manifestation of specific symptoms. Immunity develops soon after the infection, but gradually fades over time. If the SARS-CoV-2 infection manifests as a common flu or common cold, there is a possibility that the number of infections may decrease as the weather gets warmer. Another possibility is that SARS-CoV-2 supports mutations in a potentially beneficial way, making humans' infection with this virus more difficult. For example, in 2002, SARS-CoV underwent a random genetic mutation (as is usually the case with viruses), and the infection became more severe but more difficult to be transmitted to other humans. However, even if SARS-CoV-2 could become a seasonal disease, such as influenza or colds, it may have a lower impact during subsequent years, as many people have already acquired immunity, although it is not clear if people can become infected with this virus more than once [7, 20-22].

At present, there is no evidence that SARS-CoV-2 has undergone any significant mutation. The available viral sequences are almost identical, making it difficult to determine how the virus will behave. WHO insists that "there is no evidence that the virus has changed", although a report by Chinese researchers on genetic analysis among 103 patients infected with SARS-CoV-2, states that the virus has evolved into two major types (designated "S" and "L"). The "S" type $(\sim 30 \%)$ is the initial, less aggressive virus, and the "L" type $(\sim 70 \%)$ has become detached from the "S" type, being more aggressive and spreading much faster. This opinion is not shared by the $W H O$, nor by American virologists, and further research will clarify whether these genetic mutations exist. A recent study includes convincing data showing a change of amino acids within the ' $S$ ' protein of the virus (D614G). This change occurred early during the pandemic and the viruses containing this change are now stated to be prevalent in many places around the world [23].

The latest epidemiological studies have shown that the distribution of the incubation period and the distribution of the infection interval are pretty much the same [24, 25]. From $30 \%$ to $50 \%$ of transmissions are suggested to occur from pre-symptomatic persons. Considering the SARS-CoV-2 infectiousness and the high proportion of transmissions from pre-symptomatic persons, pandemic control by preventing manual contact is not feasible [26]. The incubation period for SARS-CoV-2, meaning the period from a person's exposure to the virus and the symptoms debut is about 5-6 days on average, but it can also be up to 14-16 days. During the incubation (pre-symptomatic) period, some infected persons could be contagious. Subsequently, the transmission starting from a pre-symptomatic case could take place before the symptoms debut $[22,27]$. Thus, the virus could be transmitted by the persons infected with SARS-CoV-2 before significant symptoms appear. During pre-symptomatic transmission, infectious drops and contaminated surfaces are the main factors responsible for the virus spreading [28, 29].

\section{Clinical manifestations and diagnosis of SARS-CoV-2 infection}

In most cases, SARS-CoV-2 infection is associated with the triggering of a true cytokine "storm": interleukins (IL-2, IL-6, IL-7 and IL-10), interferon (IFN)- $\gamma$-inducible protein 10, granulocyte/macrophage colony-stimulating factor (GM-CSF), macrophage inflammatory protein-1 alpha (MIP-1 $\alpha$ ), monocyte chemoattractant protein-1 (MCP-1), and tumor necrosis factor-alpha (TNF- $\alpha$ ). In those who survive intensive care, immunity will increase excessively, and its responses will lead to lung damage and/or pulmonary 
fibrosis in the long-term, resulting in a reduced quality of life. Signs and symptoms of SARS-CoV-2 may occur from day 2 to day 14 after exposure and they can include cough, fever, or shortness of breath. SARS-CoV-2 symptoms can range from very mild to very severe. Older people or people with chronic diseases (cardiovascular, diabetes, cancer) may experience acute manifestations of this disease. There is increasing data that SARS-CoV-2 infection occurs more frequently in men than in women, probably because of the ACE2 receptor, which is dependent on the "loading" of the body with sex hormones. At hospitalization, lymphocytopenia was observed in $83.2 \%$ of patients, leukopenia in $33.7 \%$ and thrombocytopenia in $36.2 \%$ of patients [30].

Confirmation of cases suspected of SARS-CoV-2 infection is done using mainly molecular [reverse transcription-polymerase chain reaction (RT-PCR)] and serological [enzyme-linked immunosorbent assay (ELISA)] tests. A comparison between the molecular and serological tests showed that the molecular test is more significant, having much better sensitivity and specificity. The evaluation of the sensitivity and specificity of both molecular and serological assays, as well as rapid test methods, remains a high priority to bring the COVID-19 pandemic under control [31, 32]. Currently, seven potential diagnostic kits are available on the market for SARS-CoV-2. A new Cochrane review assessed how accurate the tests for detecting the COVID-19 antibodies of current and past SARS-CoV-2 infection [33]. Respiratory tests were found to be positive for the virus, while the blood tests were negative in the early period of infection. It has also been suggested that in the first few days of the disease, patients have high levels of the virus, despite mild symptoms $[34,35]$.

\section{Treatment of SARS-CoV-2 infection: essential overview}

Presently, there are no specific vaccines or antiviral drugs for CoVs, although several molecules have been tested against CoVs, even for SARS-CoV-2, with over 3500 publications about the results of these tests. The main drugs used in the clinical studies are intended to restrict the components of the SARS-CoV-2 infection life cycle. These components may include: the viral access into the hosting cell [blocked by IFN, chloroquine (CQ), or umifenovir], the viral replication [blocked by darunavir/ cobicistat or lopinavir/ritonavir, both inhibiting the 3C-like protease (3CL $\left.\left.{ }^{\text {pro }}\right)\right]$ and the viral RNA synthesis (stopped by favipiravir, remdesivir, ribavirin, emtricitabine/tenofovir or alafenamide). Currently, commonly used antiviral drugs, including neuraminidase inhibitors (oseltamivir, peramivir, zanamivir, etc.) are not effective for COVID-19 because $\mathrm{CoV}$ does not produce neuraminidase. Ganciclovir, acyclovir, ribavirin, and other medicines have little effect and are not recommended for clinical application. Drugs that have been shown to be effective in current studies include: lopinavir/ritonavir or rudecvir combined with recovery plasma, IFN- $\beta$ and monoclonal antibodies [36-42].

Out of the molecules tested, we selected those that gave positive results for COVID-19 prophylaxis and treatment: $\mathrm{CQ}$, niclosamide and ivermectin, remdesivir, hesperidin, curcumin-boron complexes, and blockers of the angiotensin II type 1 (AT1) receptor ("sartans").
CQ, a known antimalarial agent, may have effects against many viruses, such as hepatitis B, human immunodeficiency virus (HIV) type 1 and human coronavirus229E (HCoV-229E), and may be immunomodulatory and anti-inflammatory as well. It is postulated that CQ works by modifying ACE2 glycosylation and altering the endosomal $\mathrm{pH}$. Its anti-inflammatory properties can be beneficial for the prevention and treatment of SARS. According to a paper issued by the International Journal of Antimicrobial Agents, on February 11 ${ }^{\text {th }}, 2020$, French researchers stated that CQ had shown its in vitro efficacy against a wide spectrum of viruses, including SARS, during the 2003 epidemic. At the same time, this drug, tested in vitro on SARS-CoV-2, has shown efficiency in blocking the replication of this virus. Thus, the Chinese authorities and the researchers who conducted the studies concluded that CQ phosphate has potential to combat COVID-19 and recommended it be mentioned in the new "Guide for the prevention, diagnosis and treatment of pneumonia caused by COVID-19", published by the National Health Commission of the People's Republic of China [43-46]. However, using hydroxychloroquine (HCQ) for humans, for which significant in vitro antiviral properties have been demonstrated, is still a topic much debated with controversial results [47-49]. There has been widespread interest in HCQ as both a preventive measure and for treating patients with COVID-19. However, another larger scale clinical trial has shown HCQ is not actually effective against SARS-CoV-2 infection. While $W H O$ has halted its clinical trials, around the world there are more than 200 other trials currently underway [50]. Our opinion and that of many scientists is that the information war over HCQ has slowed down the knowledge of COVID-19.

Niclosamide is a drug known and used mainly as an anthelmintic, having been shown to inhibit SARS-CoV-2 replication. Reduction of virus yield in infected cells was dose-dependent [51-53].

Recently, an in vivo study demonstrated the ability of ivermectin to reduce viral angiotensin receptor blocker (ARB) up to 5000 times after 48 hours of SARS-CoV-2 infection. Ivermectin is currently used as an antiparasitic for animals. In the future, further clinical studies are required in order to prove whether ivermectin is efficient to cure COVID-19 [24, 54].

Remdesivir (GS-5734) is a novel nucleoside analog and a broad-spectrum antiviral drug. In contrast to fapilavir and ribavirin, in vitro and animal experiments have confirmed that remdesivir has strong antiviral activity against human $\mathrm{CoV}$ infection and various $\mathrm{CoVs}$ isolated from bats. In theory, remdesivir is currently the most promising drug for SARS-CoV-2. The results of animal experiments showed that compared to the control group, remdesivir can effectively reduce the virus concentration in the lungs of MERS-CoV-infected mice, improving the functionality of the damaged tissue. Also, early treatment with remdesivir during infection has a clear benefit for Rhesus macaques infected with SARS-CoV-2 [55]. For humans, its efficacy is better than the combination of lopinavir/ritonavir/IFN- $\beta$. Recently, the New England Journal of Medicine issued a report about a USA patient infected with SARS-CoV-2 who was treated and cured using remdesivir [56-58]. However, there are three recent 
studies showing potential contradictory findings on the use of remdesivir against SARS-CoV-2 in humans. The most recent reported remdesivir utilization has not shown a clinical improvement, and the results are not statistically significant, while side effects are being reported as well. Subsequently, remdesivir was stopped during the clinical trial due to the side effects [59].

Hesperidin, a natural polyphenol found in Citrus spp. [60], binds to the receptor for ACE2, the gateway to SARS-CoV-2 into the human cell. Hesperidin administration significantly suppressed the expression of the ACE2 receptor protein, with inhibitory effects on virus entry into the host cells $[48,61,62]$.

Rosocyanin, a curcumin-boron complex, inactivates viral proteases. The high affinity of rosocyanin for proteases has been known for a long time [63, 64].

AT1 receptor blockers ("sartans", such as valsartan, irbesartan, losartan, candesartan, telmisartan, and eprosartan) have been widely applied since the 1990 s to control high blood pressure. Currently, complete information on the proportion of hypotensive patients among SARS-CoV-2 patients that were hospitalized is not available; it is, therefore, too early to predict the number of patients with SARS from the ongoing epidemic who could be cured with AT1 blockers, with no risk of hypotension exacerbation. The initiative of applying telmisartan and losartan (AT1 antagonists) as anti-SARS-CoV-2 therapeutic agents in order to treat patients before the occurrence of the acute respiratory syndrome, is still unproven until more tests are done. Therefore, the quickest approach to assess the feasibility of "sartans" is an analysis of patients' clinical data and the extent to which patients treated with AT1 antagonists before diagnosis (for diabetes, hypertension, kidney disease, etc.) have a good response acquiring the viral disease. There is only one study that showed that blocking AT1 receptors with losartan and inhibiting ACE2 with enalapril reduced the proportion of macrophages induced by Dengue fever virus (DENV2), a SARS-CoV-2-like RNA virus, suggesting a decrease in cell penetration by the virus and a role of ACE2 in Dengue virus infection [65-67]. The use of ACE inhibitors (ACEIs)/ ARBs for COVID-19 patients does not lead to harmful outcomes and may even provide benefits and decrease mortality from COVID-19 [68].

Next, we will investigate the most scientifically debated semisynthetic molecules (HCQ and azithromycin) and two natural compounds or derivatives (hesperidin and rosocyanin).

\section{a Efficacy and safety of chloroquines for COVID-19 treatment}

\section{Chloroquines}

In Germany, the well-known Bayer drug manufacturer synthesized CQ, an amine form of quinine, for the first time in 1934. Initially, CQ was used as a substitute for natural quinine (a molecule identified in the bark of the Cinchona trees found in Peru), which was originally chosen as a prophylactic against malaria. Subsequently, CQ became a first-line drug for the prophylaxis and treatment of malaria, becoming one of the most prescribed drugs. CQ and HCQ belong to the same family of molecular entities; HCQ is different from CQ through the hydroxylation of the $N$-ethyl substituent. HCQ is available as a phosphate or sulfate for oral administration. The pharmacokinetics of HCQ and CQ are similar, having gastrointestinal absorption and rapid renal elimination. Unfortunately, the efficiency of CQ against malaria has progressively decreased due to the continued evolution of CQ-resistant strains of Plasmodium falciparum. CQ can also be administered in the treatment of autoimmune diseases and to control inflammatory processes, and it has a wide spectrum of use against some bacterial, fungal, and viral infections $[69,70]$.

\section{Antiviral properties of chloroquines: mechanism of action and toxicity}

Studies have highlighted the antiviral effects of CQs through the following mechanisms: (i) It alters the $\mathrm{pH}$ value of endosomes, which triggers an important inhibitory effect on viral infections that invade the cells through the endosomal pathway; (ii) It influences viral replication by inhibition of virus genes expression; (iii) It interferes with ACE2 receptor glycosylation thus preventing the binding of SARS-CoV-2 to human host cells; (iv) It interferes with the infection and virus replication by affecting autophagy; (v) It influences the ' $M$ ' protein by proteolytic processing and hinders the assembly of the virion; (vi) It works as an immunomodulatory agent capable of mediating the body's anti-inflammatory response in the following diseases: lupus erythematosus, rheumatoid arthritis, and sarcoidosis [45, 46].

Recent research showed that pneumonia caused by CoVs may be closely linked to the abnormal metabolism of hemoglobin in humans [71]. CQ is a drug commonly used to treat porphyria or 'vampire disease' (a hereditary disease caused by heme synthesis disorder). Therefore, the combination of surface glycoproteins of SARS-CoV-2 with human porphyrins causes a series of pathological reactions (decreased hemoglobin), preventing the formation of the heme and practically reducing the number of red blood cells with major effects on lung oxygenation. HCQ competes with porphyrin and binds to the viral protein, thus inhibiting its attack on the heme or its binding to porphyrin [72]. The number of red blood cells is a significant biochemical indicator, and it is different between men and women. The number of erythrocytes in healthy men is considerably higher than in healthy women. This could be one reason why men are more likely to be infected with the new SARS-CoV-2 [45, 46].

Although the prolonged use of CQ as an antimalarial drug has confirmed its safety in humans, a low risk of macular retinopathy (depending on the cumulative used dose) and cardiomyopathy cannot be ignored. However, in general, CQ and HCQ are considered to be safe, having mild and transient side effects [73-76].

\section{Possible antiviral effects of chloroquine versus SARS-CoV-2}

\section{In vitro}

$\mathrm{CQ}$ is a versatile bioactive agent, with antiviral activity observed against RNA viruses: Chikungunya, Crimean hemorrhagic fever, Dengue, Ebola, Hendra, hepatitis A, hepatitis C, HIV, influenza A and B, influenza A H5N1, 
Lassa, Nipah, polio, rabies and Zika, as well as against various deoxyribonucleic acid (DNA) viruses, such as hepatitis B and Herpes simplex. The in vitro properties of HCQ were occasionally proven during the treatment of infected patients, but there was no general confirmation, with differences regarding the disease, the dosage, the treatment duration and the clinical team responsible for the study $[77,78]$.

\section{In vivo}

Based on in vitro proof, a recent clinical trial recommended the use of CQ phosphate for 10 days $(500 \mathrm{mg}$ twice a day) for cases with pneumonia (severe, moderate and mild) due to SARS-CoV-2, in which there were no contraindications to CQ phosphate. Several precautions were suggested: ( $i$ ) Blood analysis to avoid anemia, leukopenia and thrombocytopenia development, and other renal and liver dysfunctions/disorders; (ii) Routine electrocardiography to preclude bradycardia or the extension of the QT interval [79].

Recently, the National Center for Biotechnological Development, under the authority of the Ministry of Science and Technology of China, stated that CQ is one of the three promising drugs to fight the new SARS-CoV-2, with 23 clinical trials underway. CQ has been used in hospitals in Beijing, central and southern China (Guangdong Province). According to preliminary reports, Chinese authorities suggest that about 100 patients infected with the new CoV have been treated with CQ, and they have recorded a faster decrease in fever and improved computed tomography scans of the lungs, and the patients had a shorter recovery time in comparison with the control groups and with no obvious major adverse effects. Accordingly, the Chinese Medical Advisory Committee recommended the inclusion of CQ in the treatment of COVID-19 [79, 80].

In a document published on its own website, the Dutch Center for Disease Control suggested that CQ could be used to treat severe infections that require hospitalization and oxygen therapy. The suggested prescription for adults consists of the administration of $600 \mathrm{mg}$ HCQ (six tablets $\mathrm{A}-\mathrm{CQ}^{\odot} 100 \mathrm{mg}$ ) followed by $300 \mathrm{mg}$ after 12 hours on the first day, then $300 \mathrm{mg} \times 2 /$ day on the second day, up to the fifth day. This document emphasized the need to stop treatment after the fifth day in order to diminish the risk of adverse effects, given the half-life of the drug (30 hours). It is also necessary to distinguish between the doses of CQ phosphate and HCQ, since $500 \mathrm{mg}$ of CQ phosphate is equivalent to $300 \mathrm{mg}$ of HCQ [79].

Another study from the Italian Society of Infectious and Tropical Diseases (Lombardy Section) recommends the administration for 10 days of CQ $(500 \mathrm{mg} \times 2 /$ day $)$ or HCQ ( $200 \mathrm{mg} \times 2 /$ day), although the treatment may be varied between the fifth and twentieth day depending on the clinical gravity. The target category consists of people with mild respiratory manifestations and comorbidities, as well as cases with severe respiratory deficiency [79].

Just recently (March 20 ${ }^{\text {th }}, 2020$ ), a clinical trial coordinated by French professor Didier Raoult confirmed that HCQ is significantly associated with a reduction or disappearance of viral load in patients with COVID-19, the effect being reinforced by the simultaneous administration of an antibiotic (azithromycin). Thus, an acute viral disease can be successfully treated with two cheap and widely available drugs $[79,80]$.

\section{Hydroxychloroquine therapy for COVID-19}

The above-mentioned clinical trial showed that HCQ sulfate is stronger than CQ for inhibition of SARS-CoV-2 [43], being administered at a dose of $400 \mathrm{mg} \times 2 /$ day on the first day, then $200 \mathrm{mg} \times 2 /$ day for the next four days, to which $500 \mathrm{mg}$ of azithromycin was added on the first day, followed by $250 \mathrm{mg}$ daily for the next four days [81]. Comparing the effect of the treatment with HCQ with the effect of the combined treatment of HCQ and azithromycin on day 6 after initiation, it was found that $100 \%$ of the patients treated with the combined treatment (HCQ and azithromycin) were cured, as opposed to 57.1\% of the patients treated only with HCQ and $12.5 \%$ of the control group $(p<0.001)$ [44, 82]. However, several studies have shown that the high CQ dose scheme, administered for 10 days, was not entirely safe and had no clinical advantages. It remains for future clinical trials to prove the efficiency of the CQ treatment [51, 83].

A recent observational study showed that HCQ has not been associated with and has not considerably decreased the risk of death during the treatment [49]. Other studies showed that HCQ, ivermectin and azithromycin, if simultaneously administrated, seemed to potentially act against infection with the new virus. However, their efficacy should be studied individually and in combination [84]. At the same time, a combination of zinc sulfate and $\mathrm{CQ}$ may play a role in the therapeutic management of COVID-19, suggesting a potential synergic mechanism of these substances if used early during the disease course [85]. Other studies showed that the azithromycin/ nitazoxanide combination could be a more effective treatment than the HCQ/azithromycin combination as the standard treatment for early COVID-19 [54].

CQ and HCQ are known to cause heart rhythm problems that could be exacerbated if the treatment is combined with other drugs, such azithromycin, with similar effects on the heart [86]. Recent studies have reported very serious heart rhythm problems, sometimes fatal. Physicians are recommending close monitoring of COVID-19 patients that are receiving CQ and HCQ, watching for the possibility of side effects at higher doses and to be more careful when the treatment is combined with other drugs like azithromycin that can have similar side effects on the heart [87]. Short-term treatment with $\mathrm{CQ}$ is safe, but in combination with azithromycin, there may be a synergic effect on QT length, resulting in heart failure and cardiovascular mortality [88].

Recently, the Indian Council of Medical Research recommended a starting dose for HCQ of $400 \mathrm{mg}$ twice on the first day, continued with $400 \mathrm{mg}$ daily as chemoprophylaxis and treatment in patients with COVID-19 [89]. It may be necessary to administrate a loading dose followed by a maintenance dose in order to achieve optimal treatment $[43,90]$.

The discrepancies in the use of HCQ in clinical management among intensive care unit patients with severe COVID-19 requires extensive research. The lack of evidence barely justifies the widespread use of HCQ for prophylaxis. Long-term use of HCQ for the treatment 
of malaria indicates their safety during acute human administration. However, the minor risk of macular retinopathy and a prolonged QT interval in arrhythmic, renal, and hepatic impaired patients, cannot be ignored. The number of USA patients receiving prescriptions for HCQ, CQ and azithromycin increased dramatically as the COVID-19 began to unfold, according to new data. The report was issued a month after the United States Food and Drug Administration (FDA) revoked the emergency use authorization for HCQ and CQ to treat COVID-19 amid continuing concerns about the safety of widespread use of the drugs to treat the infection. Large, wellconducted, randomized clinical trials are needed to determine whether HCQ and CQ have preventative or efficacy against COVID-19 and acceptable safety. At this time, their use outside of clinical trials is not warranted. There is insufficient evidence to support the efficacy or safety of HCQ and CQ for the treatment of COVID-19 in patients $[76,91]$. Some studies show that the treatment is not harmful, but it also does not offer any benefit. The findings indicate that HCQ is not an effective treatment during hospitalization of patients with COVID-19 but does not address its use as prophylaxis or in patients with less severe community-transmitted SARS-CoV-2 infection. COVID-19 treatment with HCQ and CQ has been recommended in many treatment guidelines, including in Brazil, China, France, Italy, the Netherlands, South Korea, and the United States [73, 92]. However, recently, a multicenter study of patients hospitalized with COVID-19 in Madrid with prednisone-associated HCQ reported promising results [92].

\section{ㅁ Azithromycin as a possible anti-COVID-19 drug (prophylactic and therapeutic)}

\section{Azithromycin}

Erythromycin A and its derivatives have been widely used as oral therapy in the ambulatory treatment of respiratory diseases in humans, including in children. Azithromycin (9-deoxy-9a-aza-9a-methyl-9a-homoerithromycin A) is a structural derivative of erythromycin A, modified by the insertion of a nitrogen atom into the macrolide nucleus. This compound is stable at gastric $\mathrm{pH}$, having a high affinity for the lung tissue, due to the presence of tertiary amino groups that enhances its amphiphilic properties [93, 94].

Azithromycin was introduced on the market in 1988, and after 2000, it became a leader in the field of antibiotics used to fight respiratory tract infections. The use of azithromycin in respiratory infections is due to its location in certain potential areas of infection of human lung tissue, presenting the following maximum concentrations, after a single oral dose of $500 \mathrm{mg}: 23 \mathrm{mg} / \mathrm{L}$ in alveolar macrophages, $3.9 \mathrm{mg} / \mathrm{L}$ in bronchial mucosa, $2.2 \mathrm{mg} / \mathrm{L}$ in epithelial mucosal fluid, and $1.6 \mathrm{mg} / \mathrm{L}$ in sputum. Worldwide, azithromycin use has led to considerable stimulation of the development of bacterial and viral infection therapy [93].

\section{Mechanisms of action}

The discovery of macrolides with antibacterial, antiviral, and anti-inflammatory properties is a step forward in designing new generations of pharmacological therapies against asthma and exacerbations of chronic obstructive pulmonary disease (COPD) [95].

\section{Antibacterial and antiviral properties}

Macrolide antibiotics, such as azithromycin, exhibit bacteriostatic activity by disrupting ribosomal activity during bacterial division and by subsequent interruption of protein synthesis [95].

Macrolides have shown effects against viruses causing respiratory infections, such as influenza virus, rhinovirus, and respiratory syncytial virus (RSV). Azithromycin can prevent extracellular viruses from invading the host cell, but it does not affect the attachment of viruses to the cell surface. Therefore, azithromycin can interrupt the internalization of the virus into the host cells, in the early stage of the infection process. At the same time, due to its unique mechanism of inhibition, azithromycin acts before and after infection with the influenza virus [96, 97].

Azithromycin is also an interesting and promising molecule for therapy against infections with the Zika virus. Moreover, its administration is already approved in humans, including pregnant women. Recent studies confirmed the in vitro activity of azithromycin against Zika virus. Because there are no specific drugs or vaccines available for the Zika virus, azithromycin may be the first compound used to prevent and treat infections with this virus, with the benefit of being an approved, safe, usable and pregnancy-friendly drug. In addition, azithromycin also targets the newly developed downstream viruses released from the host cells, inactivating their endocytic penetration capacity [98-100].

\section{Anti-inflammatory properties}

Azithromycin has marked immunomodulatory effects, which gives it efficacy in reducing COPD exacerbations. It is known that azithromycin regulates the inflammatory cascade, attenuates excessive cytokine production in viral infections and may limit their exacerbation. Furthermore, azithromycin influences the activity of phagocytes, altering their functions (chemotaxis, phagocytosis, oxidative 'explosion', bactericidal effect, and cytokine production) [101-104].

\section{Toxicity}

In vivo tests have shown that azithromycin has a much lower toxicity than erythromycin A: for erythromycin A, median lethal dose $\left(\mathrm{LD}_{50}\right)$ i.v./p.o. is $360 / 4000 \mathrm{mg} / \mathrm{kg}$, while for azithromycin, $\mathrm{LD}_{50}$ i.v./p.o. is $825 / 10000 \mathrm{mg} / \mathrm{kg}$. Therapy with high-dose macrolides has been correlated with reversible hearing loss. However, the incidence of this long-term treatment effect during low-dose macrolide therapy is not well-characterized [105, 106].

\section{Azithromycin in the prophylaxis and treatment of COVID-19}

It is known that azithromycin stops the release of cytokines, which trigger lung inflammation that can kill patients with coronavirus. Azithromycin has also been shown to inhibit the production of viruses, demonstrating that a combination of HCQ and azithromycin has a syner- 
gistic in vitro effect on SARS-CoV-2 [107]. Azithromycin seems to reduce virus entry into cells. Moreover, it can augment the response of the immune system against viruses through several actions. Azithromycin regulates the production of type I and III IFNs (especially IFN- $\beta$ and IFN- $\lambda$ ) and genes involved in virus recognition, such as melanoma differentiation-associated gene 5 (MDA5) and retinoic acid-inducible gene I (RIG-I). Azithromycin regulates and/or decreases the production of IL- $1 \beta$, IL-6, IL-8, IL-10, IL-12 and IFN- $\alpha$. The inhibitory effect of azithromycin on IL-8 may also be of interest in COVID-19 therapy. Another property of azithromycin is its antibacterial effect, which may be most interesting to prevent or treat co-infections of bacteria and SARS-CoV-2 [108].

So far, a clinical trial has studied azithromycin given in combination with HCQ for the treatment of COVID19. This combination has a synergistic, strong inhibitory effect on SARS-CoV-2, being recommended as follows: HCQ at a dose of $400 \mathrm{mg} \times 2 /$ day, on the first day, then $200 \mathrm{mg} \times 2 /$ day, for a further four days, adding azithromycin at a dose of $500 \mathrm{mg} \times 1 /$ day, followed by $250 \mathrm{mg} \times 1 /$ day for the next four days. The HCQ-azithromycin combination can act both as an antiviral therapy in COVID-19 cases and also prophylactically, to counter secondary bacterial infections and the spread of the virus [108].

A recent study in Kerala (India) proved that, in a strictly monitored protocol-driven in-hospital setting, treatment with HCQ alone and HCQ + azithromycin was associated with a significant reduction in mortality among patients hospitalized with COVID-19 [109]. The study showed major gains from HCQ and azithromycin in the first 500 cases. However, the mean age of the patients was 34 , while the average age of patients in India is 37 and 63 in Italy. Also, the study had a far smaller proportion of patients with moderate to severe symptoms. In summary, there is currently no preclinical evidence or clinical care results supporting benefits from azithromycin treatment [110].

Additional studies are required. Currently, given the promising results of the above-mentioned pharmacological combination, decision makers at the international level can combat this emerging viral infection in real time, to limit the expansion of COVID-19 globally. Subsequently, other strategies and research, together with vaccine development, may also be efficient, but only after an unknown period of time $[81,82,111]$.

\section{a Hesperidin: natural candidate molecule for COVID-19 prophylaxis}

\section{Hesperidin}

Hesperidin (3',5,7-trihydroxy-4'-methoxy-flavanon7-O-ramnoglucoside) is a polyphenol/flavanone glycoside composed of a hesperetin/aglycone part and a glycosidic part (rutinose - a disaccharide composed of rhamnose and glucose). It was first isolated in 1828 by the French chemist Lebreton from the spongy inner portion (albedo) of the orange pericarp (the shells). Hesperidin is also found in the pericarp of lemon and other Citrus spp. fruits; the highest amounts were found in sweet orange (15.25 $8.21 \mathrm{mg} / 100 \mathrm{~g}$ fresh fruit of C. sinensis) $[112,113]$.

\section{Pharmacological action}

\section{Effects on the cardiovascular system}

Hesperidin (as 'vitamin P' of capillary permeability) supplementation has been used in patients with vascular disorders, and this effect has attracted considerable interest in the last decade. Due to its hyaluronidase inhibitory activity, daily administration of hesperidin $(30 \mathrm{mg})$ is recommended to increase capillary resistance [114]. The antihypertensive effects of hesperidin have been extensively studied in various pharmacodynamic models. Short-term administration of hesperidin and its aglycone (hesperetin) to hypertensive rats led to a reduction in dose-dependent systolic blood pressure. In addition, an enalapril-hesperidin combination significantly lowered blood pressure due to nitric oxide-mediated vasodilatation. However, no final conclusions about its clinical applications can be drawn from these studies. Further research should confirm whether the results obtained on animal models can be valid in humans [115].

\section{Anti-hypercholesterolemic properties}

Hesperidin significantly diminishes low-density lipoproteins (LDLs), cholesterol, total lipid, and triglyceride levels, beneficially increasing the concentration of highdensity lipoproteins (HDLs) [116, 117].

\section{Anti-inflammatory and analgesic properties}

Numerous studies have indicated that hesperidin and hesperetin are capable of reducing various inflammatory markers. Thus, Citrus spp. fruits consumption is associated with a lower risk of acute coronary events or stroke. Hesperidin has significant anti-inflammatory and analgesic effects; it is especially recommended for patients with hypersensitivity to non-steroidal anti-inflammatory drugs. Although recent research has shown the anti-inflammatory effects of Citrus spp. juices, the anti-inflammatory mechanism of hesperidin is not yet fully known; further studies are needed to elucidate the molecular inhibitory mechanisms of hesperidin [118].

\section{Antioxidant properties}

Hesperidin exhibits antioxidant effects specific to polyphenols. Along with another polyphenol (diosmin), hesperidin may act as a strong antioxidant; this explains the therapeutic benefits of this combination in chronic venous insufficiency, involving oxidative stress as a pathological mechanism [119].

\section{Antibacterial properties}

Hesperidin has a protective role against bacterial and fungal infections, being active in vitro against Escherichia coli, Bacillus subtilis, Staphylococcus aureus, Streptococcus hemolyticus, Klebsiella spp., Pseudomonas aeruginosa, Vibrio cholerae, Salmonella typhi, Shigella dysenteriae, and $S$. flexneri [112].

\section{Antiviral properties}

In vitro, in cell culture, hesperidin is active against the bladder stomatitis virus. The antiviral action of hesperidin is mediated by its anti-hyaluronidase effect. At the same time, hesperidin has been proven to be 
effective against Herpes simplex, influenza, human RSV and poliovirus type 1 (PV1), in animal models. Recently, hesperidin has been proven to have a good effect against rotavirus infections, which cause diarrhea in young children and infants [120].

\section{Toxicity}

The $\mathrm{LD}_{50}$ for hesperidin was found to be $3000 \mathrm{mg} / \mathrm{kg}$ body weight, which is 180 times higher than the daily therapeutic dose. Thus, hesperidin isolated from Citrus spp. fruits shows a good safety profile in pharmacodynamic and clinical studies [121].

\section{Hesperidin for COVID-19 prophylaxis}

Currently, there are limited antiviral strategies for treating patients that contract COVID-19; the lack of specific antiviral medicines and SARS-CoV-2 vaccines continues to aggravate the situation. Natural compounds are candidates to produce cheaper and safer drugs. Natural product-based antiviral drugs have also been used in two previous $\mathrm{CoV}$ outbreaks (MERS-CoV and SARS-CoV); this suggests that nature could offer huge potential for the approach taken against the COVID-19 pandemic. Flavonoids represent a group of polyphenolic compounds well known for their many pharmacological actions (e.g., antiviral activity) [122].

Anti-CoV therapies have as main pharmacological mechanisms: (i) The prevention of viral RNA synthesis, by acting on the genetic material of SARS-CoV-2; (ii) Inhibition of viral replication by acting on critical SARS-CoV-2 enzymes; (iii) Blocking the virus from binding to the receptors of human cells; (iv) Inhibition of the viral process of assembly and infection, by acting on structural proteins [52, 122-124].

In a few mathematical simulations, in silico, hesperidin exhibited the highest binding energy to the ' $\mathrm{S}$ ' active site of SARS-CoV-2 compared to other natural or synthetic compounds by disrupting the interaction with ACE2 (in fact this enzyme is the virus receptor on the host cell) with the receptor-binding domain (RBD) of the virus. The ACE2 enzyme has been proven to be a receptor for SARS-CoV-2, interacting with the viral ' $S$ ' glycoprotein on the ' $\mathrm{S} 1$ ' domain. Thus, to facilitate therapeutic interventions, the SARS-CoV-2 ' $\mathrm{S}$ ' glycoprotein may be considered a selective target, and the action of hesperidin targeting the binding of the virus ' $\mathrm{S}$ ' $\mathrm{RBD}$ protein to the human ACE2 enzyme may block infection. Also, recent in silico research suggests that hesperidin may bind to three key proteins of the SARS-CoV-2: the ' $S$ ' surface glycoprotein, the extracellular peptidase (PD-ACE2) and $\mathrm{M}^{\text {pro }}$ or $3 \mathrm{CL}^{\text {pro }}$ (SARS CoV-2 protease, responsible for viral replication). Four other flavonoids isolated from Citrus spp. fruits (tangeretin, hesperetin, nobiletin and naringenin), which are abundantly found in orange and lemon pericarp, have a remarkable affinity for the receptors of the three key proteins of SARS-CoV-2. This fact suggests that all of the natural flavonoids isolated from Citrus spp. fruits may contribute to the inhibition of viral infection and replication [62, 123-126].

These studies indicate that polyphenols may yield a noticeable and well-demonstrated action against corona- viruses, at least in vitro, in addition to their previously established antiviral activity in vivo. The research proves that the main mechanisms of action underlying this promising effect of polyphenols are the reduction of SARS-CoV-2 titer and the inhibition of nucleocapsid protein expression. Considering their anti-inflammatory effects, the polyphenols could be used for the treatment of respiratory complications of COVID-19. Proving the antiviral effect of polyphenols in humans requires a randomized controlled clinical trial with measurable, reproducible, and relevant clinical results. Other flavonoids, coexisting with hesperidin in Citrus peels, have also shown good binding to one or more targets, especially hesperetin (hesperidin aglycone) and naringin. The latter flavonoid also showed the ability to restrict the proinflammatory overreaction of the immune system, which could help fight severe forms of COVID-19 [127].

\section{ㅁ Rosocyanin: a promising boron- curcumin candidate compound for COVID-19 prophylaxis}

\section{Background}

Curcumin (antibacterial and antiviral) activity has been studied by various scientists. Curcumin has been proven to be effective against numerous human pathogens, such as: Staphylococcus spp., Pseudomonas spp. and Streptococcus spp., the hepatitis $\mathrm{C}$ virus, influenza virus and HIV. Curcumin alleviates the lung inflammation and macrophage activation generated by influenza virus by restricting the nuclear factor-kappa B (NF- $\kappa \mathrm{B})$ signaling pathway. Despite its impressive potential, curcumin has not yet been recognized as an antiviral therapeutic drug. The specific interaction of curcumin with integrase and protease, viral proteins playing central roles in virus replication, might represent the essential mechanism for this antiviral potential [63]. On the other hand, recently, the HIV protease was tested with a boronic compound showing sub-picomolar effects two orders of magnitude stronger than darunavir (the current HIV-approved protease inhibitor) [128].

Recently, in silico, it has also been shown that curcumin together with HCQ can destabilize the structural integrity of SARS-CoV-2 surface proteins, resulting in a proposal for in vivo combined therapy of curcumin together with HCQ [129].

Over the years, curcumin solutions or turmeric extracts have been used as coloring reagents in order to assess the amount of boron in the soil, water and foods [130].

Curcumin could be found in two tautomeric conformations (keto- and enol-), with many cis and trans isomers that may vary depending on the $\mathrm{pH}$, solvent polarity, temperature, and aromatic rings substitution. The abovementioned conformations play a very important role in the curcumin antioxidant activities, as well as in their physical and chemical properties [131]. Curcumin is insoluble in water at neutral $\mathrm{pH}$, so it has a low bioavailability, and it also decomposes and/or crystallizes in acidic and alkaline $\mathrm{pH}$ solutions. When it is taken orally, most of the curcumin never reaches the blood, being scarcely absorbed from the gut, is rapidly metabolized and excreted in the feces. 


\section{Rosocyanin}

When combining curcumin with boric acid, its esters form a complex called rosocyanin, which is regularly used to assess the amount of boron in various organic and inorganic matrices [132].

The use of rosocyanin for the development of antibacterial, anticancer, and antifungal drugs has led to the increase of a boron presence in the pharmaceutical industry [133].

At $\mathrm{pH} 2$, rosocyanin proves a charged structure because of the two $\mathrm{OH}^{+}$functional groups of the benzene ring, whereas at $\mathrm{pH} 3-5$ it has a nonionic structure [134].

Using the boron-based compounds reaction with curcumin, we enhanced its in vivo stability without bioactivity loss (i.e., antiproliferation and antioxidant effects). Recently, one study showed that a bortezomib drug co-administered with curcumin has synergistic and therapeutic activity for multiple myeloma treatment. Furthermore, the combination of 2-aminoethyl diphenyl borate with curcumin was shown to increase the in vitro and in vivo stability of curcumin [135].

Rosocyanin restricts HIV-1 and HIV-2 protease activity. Simple changes of the curcumin structure unfavorably raised its half-maximal inhibitory concentration $\left(\mathrm{IC}_{50}\right)$ value. However, the reaction of the central dihydroxy groups of curcumin with the boron atom favorably reduced the $\mathrm{IC}_{50}$ to a level of $6 \mu \mathrm{M}$ by activation of the $\alpha, \beta$ unsaturated carbonyl functional group of curcumin. Subsequently, the HIV-1 and HIV-2 inhibition was increased more than 10-fold when rosocyanin was used. These effects show that the curcumin moiety is very important to enhance the rosocyanin biological activity [64].

A recent in silico analysis, by using molecular docking, showed that curcumin can inhibit SARS-CoV-2 in a range of $3-10 \mu \mathrm{M}$. This concentration is similar to that of nelfinavir (an important antiviral drug) [136].

As a result, boron compounds with curcumin began to be increasingly investigated, discovering remarkable biological properties (antitumor, antiviral, antioxidant, and antithrombotic). It is believed that in the future these compounds could be used as drugs in the prophylaxis of pandemic viral attacks, such as SARS-CoV-2, as well as to improve blood circulation in the body. Considering the scientific arguments presented above and also the ability of curcumin to form boron complexes, several boronbased compounds could be prepared for the prevention of COVID-19 [137].

\section{a Conclusions and future perspectives}

There is insufficient preclinical and clinical evidence on HCQ effectiveness combined with azithromycin in COVID-19 treatment. Presently, there are a few scientific data that clarify how to prevent SARS-CoV-2 infection, but some conclusions can be drawn to support the positioning of azithromycin as a new active substance in the fight against COVID-19: $(i)$ Macrolides in general and azithromycin in particular are molecules with important anti-inflammatory, antibacterial and antiviral action; (ii) The HCQ-azithromycin combination represents a pharmacological therapy that should be urgently studied; (iii) In the future, azithromycin should be considered for ambulatory administration, both in children and adults, for prophylactic purposes, in order to prevent COVID-19. Moreover, Citrus spp. fruits could be approached as the best natural resources for the prophylaxis and treatment of SARS-CoV-2 infection. Hesperidin is available as a dietary supplement, a natural compound isolated from the sweet orange pericarp (C. sinensis). Because it "sticks" to the viral ' $S$ ' glycoprotein and interferes with its replication, hesperidin inhibits SARS-CoV-2. Hesperidin may also be used as an adjuvant in the treatment of high blood pressure. As well, rosocyanin, which actually is a curcuminboron complex, has been shown to be an extremely effective inhibitor of viral proteases (HIV1 and HIV2) [64] and in addition a potent chelator of free iron [134]. It is believed that in the future these compounds could be used as drugs for the prophylaxis of pandemic viral attacks, such as SARS-CoV-2.

\section{Conflict of interests}

The authors declare that they have no conflict of interests.

\section{Ethical standards}

The manuscript does not contain clinical studies or patient data.

\section{Acknowledgments}

This work was supported by a grant of the Romanian Ministry of Education and Research, CNCS-UEFISCDI, project number PN-III-P1-1.1-PD-2019-0214, within PNCDI III.

\section{References}

[1] Fehr AR, Perlman S. Coronaviruses: an overview of their replication and pathogenesis. Methods Mol Biol, 2015, 1282: 1-23. https://doi.org/10.1007/978-1-4939-2438-7_1 PMID: 25720466 PMCID: PMC4369385

[2] Cui J, Li F, Shi ZL. Origin and evolution of pathogenic coronaviruses. Nat Rev Microbiol, 2019, 17(3):181-192. https:// doi.org/10.1038/s41579-018-0118-9 PMID: 30531947 PMCID: PMC7097006

[3] Liu P, Jiang JZ, Wan XF, Hua Y, Li L, Zhou J, Wang X, Hou F, Chen J, Zou J, Chen J. Are pangolins the intermediate host of the 2019 novel coronavirus (SARS-CoV-2)? PLoS Pathog, 2020, 16(5):e1008421. https://doi.org/10.1371/journal.ppat.10 08421 PMID: 32407364 PMCID: PMC7224457

[4] Mallapaty S. Animal source of the coronavirus continues to elude scientists. Nature, 2020 May 18. https://doi.org/10.10 38/d41586-020-01449-8 PMID: 32427902

[5] Yuan S, Jiang SC, Li ZL. Analysis of possible intermediate hosts of the new coronavirus SARS-CoV-2. Front Vet Sci, 2020, 7:379. https://doi.org/10.3389/fvets.2020.00379 PMID: 32582786 PMCID: PMC7297130

[6] Fung TS, Liu DX. Human coronavirus: host-pathogen interaction. Annu Rev Microbiol, 2019, 73:529-557. https://doi.org/10.11 46/annurev-micro-020518-115759 PMID: 31226023

[7] Rabi FA, Al Zoubi MS, Kasasbeh GA, Salameh DM, AlNasser AD. SARS-CoV-2 and coronavirus disease 2019: what we know so far. Pathogens, 2020, 9(3):231. https:// doi.org/10.3390/pathogens9030231 PMID: 32245083 PMCID: PMC7157541

[8] Valencia DN. Brief review on COVID-19: the 2020 pandemic caused by SARS-CoV-2. Cureus, 2020, 12(3):e7386. https:// doi.org/10.7759/cureus.7386 PMID: 32337113 PMCID: PMC7179986

[9] Gordon DE, Jang GM, Bouhaddou M, Xu J, Obernier K, White KM, O'Meara MJ, Rezelj VV, Guo JZ, Swaney DL, Tummino TA, Hüttenhain $R$, Kaake RM, Richards $A L$, Tutuncuoglu B, Foussard H, Batra J, Haas K, Modak M, Kim M, Haas P, Polacco BJ, Braberg H, Fabius JM, Eckhardt M, 
Soucheray M, Bennett MJ, Cakir M, McGregor MJ, Li Q, Meyer B, Roesch F, Vallet T, Mac Kain A, Miorin L, Moreno E, Naing ZZC, Zhou Y, Peng S, Shi Y, Zhang Z, Shen W, Kirby IT, Melnyk JE, Chorba JS, Lou K, Dai SA, BarrioHernandez I, Memon D, Hernandez-Armenta C, Lyu J, Mathy CJP, Perica T, Pilla KB, Ganesan SJ, Saltzberg DJ, Rakesh R, Liu X, Rosenthal SB, Calviello L, Venkataramanan S, Liboy-Lugo J, Lin Y, Huang XP, Liu Y, Wankowicz SA Bohn M, Safari M, Ugur FS, Koh C, Savar NS, Tran QD, Shengjuler D, Fletcher SJ, O'Neal MC, Cai Y, Chang JCJ, Broadhurst DJ, Klippsten S, Sharp PP, Wenzell NA, KuzuogluOzturk D, Wang HY, Trenker R, Young JM, Cavero DA, Hiatt J, Roth TL, Rathore U, Subramanian A, Noack J, Hubert M, Stroud RM, Frankel AD, Rosenberg OS, Verba KA, Agard DA, Ott M, Emerman M, Jura N, von Zastrow M, Verdin E, Ashworth A, Schwartz O, d'Enfert C, Mukherjee S, Jacobson M, Malik HS, Fujimori DG, Ideker T, Craik CS, Floor SN, Fraser JS, Gross JD, Sali A, Roth BL, Ruggero D, Taunton J, Kortemme T, Beltrao P, Vignuzzi M, García-Sastre A, Shokat KM, Shoichet BK, Krogan NJ. A SARS-CoV-2 protein interaction map reveals targets for drug repurposing. Nature, 2020, 583(7816):459-468. https://doi.org/10.1038/s41586-0202286-9 PMID: 32353859 PMCID: PMC7431030

[10] RayBiotech. COVID-19 proteins: recombinant SARS-CoV-2 proteins. RayBiotech Life, Peachtree Corners, GA, USA, (accessed: 15 April 2020). https://www.raybiotech.com/covid 19-proteins/

[11] Shang J, Ye G, Shi K, Wan Y, Luo C, Aihara H, Geng Q, Auerbach A, Li F. Structural basis of receptor recognition by SARS-CoV-2. Nature, 2020, 581(7807):221-224. https://doi. org/10.1038/s41586-020-2179-y PMID: 32225175 PMCID: PMC7328981

[12] Verdecchia P, Cavallini C, Spanevello A, Angeli F. The pivotal link between ACE2 deficiency and SARS-CoV-2 infection. Eur J Intern Med, 2020, 76:14-20. https://doi.org/10.1016/j. ejim.2020.04.037 PMID: 32336612 PMCID: PMC7167588

[13] Wang K, Chen W, Zhou YS, Lian JQ, Zhang Z, Du P, Gong L, Zhang Y, Cui HY, Geng JJ, Wang B, Sun XX, Wang CF, Yang $X$, Lin $P$, Deng YQ, Wei D, Yang XM, Zhu YM, Zhang $K$ Zheng ZH, Miao JL, Guo T, Shi Y, Zhang J, Fu L, Wang QY, Bian $\mathrm{H}$, Zhu P, Chen ZN. SARS-CoV-2 invades host cells via a novel route: CD147-spike protein. bioRxiv, 2020 Mar 14. https://doi.org/10.1101/2020.03.14.988345

[14] Gelman R, Bayatra A, Kessler A, Schwartz A, llan Y. Targeting SARS-CoV-2 receptors as a means for reducing infectivity and improving antiviral and immune response: an algorithmbased method for overcoming resistance to antiviral agents. Emerg Microbes Infect, 2020, 9(1):1397-1406. https://doi.org/ 10.1080/22221751.2020.1776161 PMID: 32490731 PMCID: PMC7473106

[15] Ibrahim IM, Abdelmalek DH, Elshahat ME, Elfiky AA. COVID-19 spike-host cell receptor GRP78 binding site prediction. J Infect, 2020, 80(5):554-562. https://doi.org/10.1016/j.jinf.2020.02.026 PMID: 32169481 PMCID: PMC7102553

[16] Palmeira A, Sousa E, Köseler A, Sabirli R, Gören T, Türkçüer İ, Kurt Ö, Pinto MM, Vasconcelos MH. Preliminary virtual screening studies to identify GRP78 inhibitors which may interfere with SARS-CoV-2 infection. Pharmaceuticals (Basel), 2020, 13(6):132. https://doi.org/10.3390/ph13060132 PMID: 32630514 PMCID: PMC7345920

[17] Ulrich H, Pillat MM. CD147 as a target for COVID-19 treatment: suggested effects of azithromycin and stem cell engagement. Stem Cell Rev Rep, 2020, 16(3):434-440. https://doi.org/ 10.1007/s12015-020-09976-7 PMID: 32307653 PMCID: PMC7167302

[18] Zhou P, Yang XL, Wang XG, Hu B, Zhang L, Zhang W, Si HR, Zhu Y, Li B, Huang CL, Chen HD, Chen J, Luo Y, Guo H, Jiang $R D$, Liu $M Q$, Chen $Y$, Shen $X R$, Wang $X$, Zheng $X S$, Zhao K, Chen QJ, Deng F, Liu LL, Yan B, Zhan FX, Wang YY, Xiao GF, Shi ZL. A pneumonia outbreak associated with a new coronavirus of probable bat origin. Nature, 2020, 579(7798): 270-273. https://doi.org/10.1038/s41586-020-2012-7 PMID: 32015507 PMCID: PMC7095418

[19] Coutard B, Valle C, de Lamballerie X, Canard B, Seidah NG, Decroly $E$. The spike glycoprotein of the new coronavirus 2019-nCoV contains a furin-like cleavage site absent in CoV of the same clade. Antiviral Res, 2020, 176:104742. https://doi. org/10.1016/j.antiviral.2020.104742 PMID: 32057769 PMCID: PMC7114094

[20] Abduljalil JM, Abduljalil BM. Epidemiology, genome, and clinical features of the pandemic SARS-CoV-2: a recent view. New Microbes New Infect, 2020, 35:100672. https://doi.org/10.10 16/j.nmni.2020.100672 PMID: 32322400 PMCID: PMC7171182

[21] Hick JL, Hanfling D, Wynia MK, Pavia AT. Duty to plan: health care, crisis standards of care, and novel coronavirus SARS-CoV-2. Discussion Paper, National Academy of Medicine, Washington, DC, USA, accessed: 25 March 2020. https:// nam.edu/duty-to-plan-health-care-crisis-standards-of-care-andnovel-coronavirus-SARS-CoV-2/

[22] Lauer SA, Grantz KH, Bi Q, Jones FK, Zheng Q, Meredith HR, Azman AS, Reich NG, Lessler J. The incubation period of coronavirus disease 2019 (COVID-19) from publicly reported confirmed cases: estimation and application. Ann Intern Med, 2020, 172(9):577-582. https://doi.org/10.7326/M20-0504 PMID: 32150748 PMCID: PMC7081172

[23] Grubaugh ND, Hanage WP, Rasmussen AL. Making sense of mutation: what D614G means for the COVID-19 pandemic remains unclear. Cell, 2020, 182(4):794-795. https://doi. org/10.1016/j.cell.2020.06.040 PMID: 32697970 PMCID: PMC7332445

[24] Tu YF, Chien CS, Yarmishyn AA, Lin YY, Luo YH, Lin YT, Lai WY, Yang DM, Chou SJ, Yang YP, Wang ML, Chiou SH. A review of SARS-CoV-2 and the ongoing clinical trials. Int $\mathrm{J}$ Mol Sci, 2020, 21(7):2657. https://doi.org/10.3390/ijms2107 2657 PMID: 32290293 PMCID: PMC7177898

[25] Wu D, Wu T, Liu Q, Yang Z. The SARS-CoV-2 outbreak: what we know. Int J Infect Dis, 2020, 94:44-48. https://doi.org/10. 1016/j.jij.2020.03.004 PMID: 32171952 PMCID: PMC7102543

[26] Ferretti L, Wymant C, Kendall M, Zhao L, Nurtay A, AbelerDörner L, Parker M, Bonsall D, Fraser C. Quantifying SARSCoV-2 transmission suggests epidemic control with digital contact tracing. Science, 2020, 368(6491):eabb6936. https:// doi.org/10.1126/science.abb6936 PMID: 32234805 PMCID: PMC7164555

[27] Tong ZD, Tang A, Li KF, Li P, Wang HL, Yi JP, Zhang YL, Yan JB. Potential presymptomatic transmission of SARSCoV-2, Zhejiang Province, China, 2020. Emerg Infect Dis, 2020, 26(5):1052-1054. https://doi.org/10.3201/eid2605.200 198 PMID: 32091386 PMCID: PMC7181913

[28] Kimball A, Hatfield KM, Arons M, James A, Taylor J, Spicer K, Bardossy AC, Oakley LP, Tanwar S, Chisty Z, Bell JM, Methner M, Harney J, Jacobs JR, Carlson CM, McLaughlin HP, Stone N, Clark S, Brostrom-Smith C, Page LC, Kay M, Lewis J, Russell D, Hiatt B, Gant J, Duchin JS, Clark TA, Honein MA, Reddy SC, Jernigan JA; Public Health - Seattle \& King County; CDC COVID-19 Investigation Team. Asymptomatic and presymptomatic SARS-CoV-2 infections in residents of a long-term care skilled nursing facility - King County, Washington, March 2020. MMWR Morb Mortal Wkly Rep, 2020, 69(13):377-381. https://doi.org/10.15585/mmwr.mm69 13e1 PMID: 32240128 PMCID: PMC7119514

[29] Wei WE, Li Z, Chiew CJ, Yong SE, Toh MP, Lee VJ. Presymptomatic transmission of SARS-CoV-2 - Singapore, January 23-March 16, 2020. MMWR Morb Mortal Wkly Rep, 2020, 69(14):411-415. https://doi.org/10.15585/mmwr.mm69 14e1 PMID: 32271722 PMCID: PMC7147908

[30] Yang W, Cao Q, Qin L, Wang X, Cheng Z, Pan A, Dai J, Sun Q, Zhao F, Qu J, Yan F. Clinical characteristics and imaging manifestations of the 2019 novel coronavirus disease (COVID-19): a multi-center study in Wenzhou City, Zhejiang, China. J Infect, 2020, 80(4):388-393. https://doi.org/10.1016/ j.jinf.2020.02.016 PMID: 32112884 PMCID: PMC7102539

[31] Lisboa Bastos M, Tavaziva G, Abidi SK, Campbell JR, Haraoui LP, Johnston JC, Lan Z, Law S, MacLean E, Trajman A, Menzies D, Benedetti A, Ahmad Khan F. Diagnostic accuracy of serological tests for COVID-19: systematic review and metaanalysis. BMJ, 2020, 370:m2516. https://doi.org/10.1136/bmj. m2516 PMID: 32611558 PMCID: PMC7327913

[32] Venter M, Richter K. Towards effective diagnostic assays for COVID-19: a review. J Clin Pathol, 2020, 73(7):370-377. https://doi.org/10.1136/jclinpath-2020-206685 PMID: 32404473

[33] Deeks JJ, Dinnes J, Takwoingi Y, Davenport C, Spijker R, Taylor-Phillips S, Adriano A, Beese S, Dretzke J, Ferrante di Ruffano L, Harris IM, Price MJ, Dittrich S, Emperador D, 
Hooft L, Leeflang MM, Van den Bruel A; Cochrane COVID-19 Diagnostic Test Accuracy Group. Antibody tests for identification of current and past infection with SARS-CoV-2. Cochrane Database Syst Rev, 2020, 6(6):CD013652. https://doi.org/ 10.1002/14651858.CD013652 PMID: 32584464 PMCID: PMC7387103

[34] Pang J, Wang MX, Ang IYH, Tan SHX, Lewis RF, Chen JI, Gutierrez RA, Gwee SXW, Chua PEY, Yang Q, Ng XY, Yap RK, Tan HY, Teo YY, Tan CC, Cook AR, Yap JC, Hsu LY. Potential rapid diagnostics, vaccine and therapeutics for 2019 novel coronavirus (2019-nCoV): a systematic review. J Clin Med, 2020, 9(3):623. https://doi.org/10.3390/jcm9030623 PMID: 32110875 PMCID: PMC7141113

[35] Park SE. Epidemiology, virology, and clinical features of severe acute respiratory syndrome - coronavirus-2 (SARS-CoV-2 Coronavirus Disease-19). Clin Exp Pediatr, 2020, 63(4):119124. https://doi.org/10.3345/cep.2020.00493 PMID: 32252141 PMCID: PMC7170784

[36] European Centre for Disease Prevention and Control (ECDPC) COVID-19. European Union (EU), Solna, Sweden, accessed: 18 March 2020. https://www.ecdc.europa.eu/en/covid-19-pandemic

[37] Elsevier. Elsevier's free health and medical research on the novel coronavirus (SARS-CoV-2) and COVID-19. Nove Coronavirus Information Center, accessed: 15 April 2020 https://www.elsevier.com/connect/coronavirus-informationcenter

[38] National Center for Biotechnology Information (NCBI) GenBank SARS-CoV-2 (severe acute respiratory syndrome coronavirus 2) sequences. U.S. National Library of Medicine (NLM), Nationa Institutes of Health (NIH), Bethesda, accessed: 28 March 2020. https://www.ncbi.nlm.nih.gov/genbank/sars-cov-2-seqs/

[39] The New England Journal of Medicine (NEJM). Coronavirus (Covid-19). Massachusetts Medical Society, Boston, MA, USA, accessed: 10 April 2020. https://www.nejm.org/coronavirus

[40] Princeton Staff, 2020. For immediate release: coronavirus (SARS-CoV-2) exposure investigation initiated. Press Release, Municipality of Princeton, Princeton, NJ, USA, accessed 14 March 2020. https://www. princetonnj.gov/news/covid-19update-3-11-2020

[41] Schwartz D. Breaking research on COVID-19 pandemic: shared collection. Read by QxMD Software Inc., accessed: 12 March 2020. https://read.qxmd.com/collection/19211

[42] Springer Nature. News: coronavirus latest. Springer Nature Ltd., accessed: 21 January 2020. https://www.nature.com/ articles/d41586-020-00154-w

[43] Colson P, Rolain JM, Lagier JC, Brouqui P, Raoult D. Chloroquine and hydroxychloroquine as available weapons to fight COVID-19. Int J Antimicrob Agents, 2020, 55(4):105932. https://doi.org/10.1016/j.jantimicag.2020.105932 PMID: 32145363 PMCID: PMC7135139

[44] Devaux CA, Rolain JM, Colson P, Raoult D. New insights on the antiviral effects of chloroquine against coronavirus: what to expect for COVID-19? Int J Antimicrob Agents, 2020 55(5):105938. https://doi.org/10.1016/j.ijantimicag.2020.105 938 PMID: 32171740 PMCID: PMC7118659

[45] Savarino A, Boelaert JR, Cassone A, Majori G, Cauda R. Effects of chloroquine on viral infections: an old drug against today's diseases? Lancet Infect Dis, 2003, 3(11):722-727. https://doi.org/10.1016/s1473-3099(03)00806-5 PMID: 14592603 PMCID: PMC7128816

[46] Savarino A, Di Trani L, Donatelli I, Cauda R, Cassone A. New insights into the antiviral effects of chloroquine. Lancet Infect Dis, 2006, 6(2):67-69. https://doi.org/10 1016/S14733099(06)70361-9 PMID: 16439323 PMCID: PMC7129107

[47] Al-Bari MAA. Chloroquine analogues in drug discovery: new directions of uses, mechanisms of actions and toxic manifestations from malaria to multifarious diseases. J Antimicrob Chemother, 2015, 70(6):1608-1621. https://doi.org/10.1093/ jac/dkv018 PMID: 25693996

[48] Chen YW, Yiu CB, Wong KY. Prediction of the SARS-CoV-2 (2019-nCoV) $3 C$-like protease $\left(3 \mathrm{CL}^{\text {pro }}\right)$ structure: virtual screening reveals velpatasvir, ledipasvir, and other drug repurposing candidates. F1000Res, 2020, 9:129. https://doi.org/10.12688/ f1000research.22457.2 PMID: 32194944 PMCID: PMC7062204

[49] Geleris J, Sun Y, Platt J, Zucker J, Baldwin M, Hripcsak G Labella A, Manson DK, Kubin C, Barr RG, Sobieszczyk ME, Schluger NW. Observational study of hydroxychloroquine in hospitalized patients with Covid-19. N Engl J Med, 2020,
382(25):2411-2418. https://doi.org/10.1056/NEJMoa2012410 PMID: 32379955 PMCID: PMC7224609

[50] US Food \& Drug Administration (FDA). Coronavirus (COVID19) update: FDA revokes emergency use authorization for chloroquine and hydroxychloroquine. FDA News Release, accessed: 23 June 2020. https://www.fda.gov/news-events/ press-announcements/coronavirus-covid-19-update-fdarevokes-emergency-use-authorization-chloroquine-and

[51] Jeon S, Ko M, Lee J, Choi I, Byun SY, Park S, Shum D, Kim S. Identification of antiviral drug candidates against SARS-CoV-2 from FDA-approved drugs. Antimicrob Agents Chemother, 2020, 64(7):e00819-20. https://doi.org/10.1128/ AAC.00819-20 PMID: 32366720 PMCID: PMC7318052

[52] Wu CJ, Jan JT, Chen CM, Hsieh HP, Hwang DR, Liu HW, Liu CY, Huang HW, Chen SC, Hong CF, Lin RK, Chao YS, Hsu JT. Inhibition of severe acute respiratory syndrome coronavirus replication by niclosamide. Antimicrob Agents Chemother, 2004, 48(7):2693-2696. https://doi.org/10.1128/AAC.48.7.26 93-2696.2004 PMID: 15215127 PMCID: PMC434198

[53] Xu J, Shi PY, Li H, Zhou J. Broad spectrum antiviral agent niclosamide and its therapeutic potential. ACS Infect Dis, 2020, 6(5):909-915. https://doi.org/10.1021/acsinfecdis.0c0 0052 PMID: 32125140 PMCID: PMC7098069

[54] Kelleni MT. Nitazoxanide/azithromycin combination for COVID19: a suggested new protocol for early management. Pharmacol Res, 2020, 157:104874. https://doi.org/10.1016/j.phrs.2020. 104874 PMID: 3236058 PMCID: PMC7192107

[55] Williamson BN, Feldmann F, Schwarz B, Meade-White K, Porter DP, Schulz J, van Doremalen N, Leighton I, Yinda CK Pérez-Pérez L, Okumura A, Lovaglio J, Hanley PW, Saturday G, Bosio CM, Anzick S, Barbian K, Cihlar T, Martens C, Scott DP, Munster VJ, de Wit E. Clinical benefit of remdesivir in rhesus macaques infected with SARS-CoV-2. Nature, 2020, 585(7824): 273-276. https://doi.org/10.1038/s41586-020-2423-5 PMID: 32516797 PMCID: PMC7486271

[56] Gordon CJ, Tchesnokov EP, Woolner E, Perry JK, Feng JY, Porter DP, Götte M. Remdesivir is a direct-acting antiviral that inhibits RNA-dependent RNA polymerase from severe acute respiratory syndrome coronavirus 2 with high potency. J Biol Chem, 2020, 295(20):6785-6797. https://doi.org/10.1074/jbc. RA120.013679 PMID: 32284326 PMCID: PMC7242698

[57] Grein J, Ohmagari N, Shin D, Diaz G, Asperges E, Castagna A, Feldt T, Green G, Green ML, Lescure FX, Nicastri E, Oda R, Yo K, Quiros-Roldan E, Studemeister A, Redinski J, Ahmed S, Bernett J, Chelliah D, Chen D, Chihara S, Cohen SH, Cunningham J, D'Arminio Monforte A, Ismail $S$, Kato $H$, Lapadula G, L'Her E, Maeno T, Majumder S, Massari M, Mora-Rillo M, Mutoh $Y$, Nguyen D, Verweij E, Zoufaly A, Osinusi AO, DeZure A, Zhao Y, Zhong L, Chokkalingam A, Elboudwarej E, Telep L, Timbs L, Henne I, Sellers S, Cao H, Tan SK, Winterbourne L, Desai P, Mera R, Gaggar A, Myers RP Brainard DM, Childs R, Flanigan T. Compassionate use of remdesivir for patients with severe Covid-9. N Engl J Med, 2020, 382(24):2327-2336. https://doi.org/10.1056/NEJMoa 2007016 PMID: 32275812 PMCID: PMC7169476

[58] Wang M, Cao R, Zhang L, Yang X, Liu J, Xu M, Shi Z, Hu Z, Zhong W, Xiao G. Remdesivir and chloroquine effectively inhibit the recently emerged novel coronavirus (2019-nCoV) in vitro. Cell Res, 2020, 30(3):269-271. https://doi.org/10.1038/ s41422-020-0282-0 PMID: 32020029 PMCID: PMC7054408

[59] Wang Y, Zhang D, Du G, Du R, Zhao J, Jin Y, Fu S, Gao L, Cheng Z, Lu Q, Hu Y, Luo G, Wang K, Lu Y, Li H, Wang S, Ruan S, Yang C, Mei C, Wang Y, Ding D, Wu F, Tang $X$, Ye X, Ye Y, Liu B, Yang J, Yin W, Wang A, Fan G, Zhou F, Liu Z, Gu X, Xu J, Shang L, Zhang Y, Cao L, Guo T, Wan Y, Qin H, Jiang Y, Jaki T, Hayden FG, Horby PW, Cao B, Wang C. Remdesivir in adults with severe COVID-19: a randomised, double-blind, placebo-controlled, multicentre trial. Lancet, 2020, 395(10236):1569-1578. https://doi.org/10.1016/S01406736(20)31022-9 PMID: 32423584 PMCID: PMC7190303

[60] Binkowska I. Hesperidin: synthesis and characterization of bioflavonoid complex. SN Appl Sci, 2020, 2(3):445. https:// doi.org/10.1007/s42452-020-2256-8

[61] Chen J, Liu D, Liu L, Liu P, Xu Q, Xia L, Ling Y, Huang D, Song S, Zhang D, Qian Z, Li T, Shen Y, Lu H. [A pilot study of hydroxychloroquine in treatment of patients with moderate COVID-19]. Zhejiang Da Xue Xue Bao Yi Xue Ban (J Zhejiang 
Univ Med Sci), 2020, 49(2):215-219. https://doi.org/10.3785/ j.issn.1008-9292.2020.03.03 PMID: 32391667

[62] Wu C, Liu Y, Yang Y, Zhang P, Zhong W, Wang Y, Wang Q, Xu Y, Li M, Li X, Zheng M, Chen L, Li H. Analysis of therapeutic targets for SARS-CoV-2 and discovery of potential drugs by computational methods. Acta Pharm Sin B, 2020 , 10(5):766-788. https://doi.org/10.1016/j.apsb.2020.02.008 PMID: 32292689 PMCID: PMC7102550

[63] Praditya D, Kirchhoff L, Brüning J, Rachmawati H, Steinmann J, Steinmann E. Anti-infective properties of the golden spice curcumin. Front Microbiol, 2019, 10:912. https://doi.org/10.33 89/fmicb.2019.00912 PMID: 31130924 PMCID: PMC6509173

[64] Sui Z, Salto R, Li J, Craik C, Ortiz de Montellano PR. Inhibition of the HIV-1 and HIV-2 proteases by curcumin and curcumin boron complexes. Bioorg Med Chem, 1993, 1(6):415-422. https:// doi.org/10.1016/s0968-0896(00)82152-5 PMID: 8087563

[65] Li G, Hu R, Zhang X. Antihypertensive treatment with ACEI/ ARB of patients with COVID-19 complicated by hypertension. Hypertens Res, 2020, 43(6):588-590. https://doi.org/10.1038/ s41440-020-0433-1 PMID: 32231220 PMCID: PMC7103897

[66] Tignanelli CJ, Ingraham NE, Sparks MA, Reilkoff R, Bezdicek T, Benson B, Schacker T, Chipman JG, Puskarich MA. Antihypertensive drugs and risk of COVID-19? Lancet Respir Med, 2020, 8(5):e30-e31. https://doi.org/10.1016/S2213-2600(20) 30153-3 PMID: 32222166 PMCID: PMC7194709

[67] Zeinalian M, Salari-Jazi A, Jannesari A, Khanahmad $H$. A potential protective role of losartan against coronavirusinduced lung damage. Infect Control Hosp Epidemiol, 2020, 41(6):752-753. https://doi.org/10.1017/ice.2020.80 PMID: 32248854 PMCID: PMC7137531

[68] Qu G, Shu L, Song EJ, Verghese D, Uy JP, Cheng C, Zhou Q, Yang H, Guo Z, Chen M, Sun C. Association between angiotensin-converting enzyme inhibitors and angiotensin II receptor blockers use and the risk of infection and clinical outcome of COVID-19: a comprehensive systematic review and meta-analysis. medRxiv, 2020 Jul 3. https://doi.org/10. 1101/2020.07.02.20144717

[69] Parhizgar AR, Tahghighi A. Introducing new antimalarial analogues of chloroquine and amodiaquine: a narrative review. Iran J Med Sci, 2017, 42(2):115-128. PMID: 28360437 PMCID: PMC5366359

[70] Shukla AM, Wagle Shukla A. Expanding horizons for clinical applications of chloroquine, hydroxychloroquine, and related structural analogues. Drugs Context, 2019, 8:2019-9-1. https://doi.org/10.7573/dic.2019-9-1 PMID: 31844421 PMCID: PMC6905642

[71] Abrahams L. COVID-19: acquired acute porphyria hypothesis OSF Preprints, 2020 Apr 6. https://doi.org/10.31219/osf.io/ 4wkfy

[72] Scholnick PL, Epstein J, Marver HS. The molecular basis of the action of chloroquine in porphyria cutanea tarda. J Invest Dermatol, 1973, 61(4):226-232. https://doi.org/10.1111/15231747.ep12676478 PMID: 4744026

[73] COVID-19 RISK and Treatments (CORIST) Collaboration. Use of hydroxychloroquine in hospitalised COVID-19 patients is associated with reduced mortality: findings from the observational multicentre Italian CORIST study. Eur J Intern Med, 2020 Aug 25:S0953-6205(20)30335-6. https://doi.org/10.1016/ j.ejim.2020.08.019 PMID: 32859477 PMCID: PMC7446618

[74] Chatre C, Roubille F, Vernhet H, Jorgensen C, Pers YM. Cardiac complications attributed to chloroquine and hydroxychloroquine: a systematic review of the literature. Drug Saf, 2018, 41(10):919-931. https://doi.org/10.1007/s40264-0180689-4 PMID: 29858838

[75] Weniger $\mathrm{H}$. Review of side effects and toxicity of chloroquine. Technical Document No. WHO/MAL/79.906, World Health Organization (WHO), Geneva, Switzerland, 1979, 2-18. https://apps.who.int/iris/bitstream/handle/10665/65773/WHO_ MAL 79.906. pdf?sequence $=1$ \&isAllowed $=y$

[76] White NJ, Watson JA, Hoglund RM, Chan XHS, Cheah PY, Tarning J. COVID-19 prevention and treatment: a critical analysis of chloroquine and hydroxychloroquine clinical pharmacology. Mahidol Oxford Tropical Medicine Research Unit (MORU), Tropical Health Network, accessed: 30 June 2020. https://www.tropmedres.ac/news/covid-19-preventionand-treatment-a-critical-analysis-of-chloroquine-and-hydroxy chloroquine-clinical-pharmacology
[77] Liu J, Cao R, Xu M, Wang X, Zhang H, Hu H, Li Y, Hu Z, Zhong W, Wang M. Hydroxychloroquine, a less toxic derivative of chloroquine, is effective in inhibiting SARS-CoV-2 infection in vitro. Cell Discov, 2020, 6:16. https://doi.org/10.1038/s41 421-020-0156-0 PMID: 32194981 PMCID: PMC7078228

[78] Yao X, Ye F, Zhang M, Cui C, Huang B, Niu P, Liu X, Zhao L, Dong E, Song C, Zhan S, Lu R, Li H, Tan W, Liu D. In vitro antiviral activity and projection of optimized dosing design of hydroxychloroquine for the treatment of severe acute respiratory syndrome coronavirus 2 (SARS-CoV-2). Clin Infect Dis, 2020, 71(15):732-739. https://doi.org/10.1093/cid/ciaa237 PMID: 32150618 PMCID: PMC7108130

[79] Cortegiani A, Ingoglia G, Ippolito M, Giarratano A, Einav S. A systematic review on the efficacy and safety of chloroquine for the treatment of COVID-19. J Crit Care, 2020, 57:279-283. https://doi.org/10.1016/j.jcrc.2020.03.005 PMID: 32173110 PMCID: PMC7270792

[80] Zhu RF, Gao YL, Robert SH, Gao JP, Yang SG, Zhu CT. Systematic review of the registered clinical trials for coronavirus disease 2019 (COVID-19). J TransI Med, 2020, 18(1):274. https://doi.org/10.1186/s12967-020-02442-5 PMID: 32631442 PMCID: PMC7338108

[81] Gautret P, Lagier JC, Parola P, Hoang VT, Meddeb L, Sevestre J, Mailhe M, Doudier B, Aubry C, Amrane S, Seng P, Hocquart M, Eldin C, Finance J, Vieira VE, Tissot-Dupont HT, Honoré S, Stein A, Million M, Colson P, La Scola B, Veit V, Jacquier A, Deharo JC, Drancourt M, Fournier PE, Rolain JM, Brouqui P, Raoult D. Clinical and microbiological effect of a combination of hydroxychloroquine and azithromycin in 80 COVID-19 patients with at least a six-day follow up: a pilot observational study. Travel Med Infect Dis, 2020, 34:101663. https://doi.org/10.1016/j.tmaid.2020.101663 PMID: 32289548 PMCID: PMC7151271

[82] Gautret P, Lagier JC, Parola P, Hoang VT, Meddeb L, Mailhe M, Doudier B, Courjon J, Giordanengo V, Vieira VE, Tissot Dupont $\mathrm{H}$, Honoré $\mathrm{S}$, Colson $\mathrm{P}$, Chabrière $\mathrm{E}$, La Scola $\mathrm{B}$, Rolain JM, Brouqui $P$, Raoult D. Hydroxychloroquine and azithromycin as a treatment of COVID-19: results of an openlabel non-randomized clinical trial. Int J Antimicrob Agents, 2020, 56(1):105949. https://doi.org/10.1016/j.jijantimicag.2020. 105949 PMID: 32205204 PMCID: PMC7102549

[83] Borba MGS, Val FFA, Sampaio VS, Alexandre MAA, Melo GC, Brito M, Mourão MPG, Brito-Sousa JD, Baía-da-Silva D, Guerra MVF, Hajjar LA, Pinto RC, Balieiro AAS, Pacheco AGF, Santos JDO Jr, Naveca FG, Xavier MS, Siqueira AM, Schwarzbold A, Croda J, Nogueira ML, Romero GAS, Bassat Q, Fontes CJ, Albuquerque BC, Daniel-Ribeiro CT, Monteiro WM, Lacerda MVG; CloroCovid-19 Team. Effect of high vs low doses of chloroquine diphosphate as adjunctive therapy for patients hospitalized with severe acute respiratory syndrome coronavirus 2 (SARS-CoV-2) infection: a randomized clinical trial. JAMA Netw Open, 2020, 3(4):e208857. https://doi.org/ 10.1001/jamanetworkopen.2020.8857 PMID: 32330277

[84] Choudhary R, Sharma AK. Potential use of hydroxychloroquine, ivermectin and azithromycin drugs in fighting COVID-19: trends, scope and relevance. New Microbes New Infect, 2020, 35: 100684. https://doi.org/10.1016/j.nmni.2020.100684 PMID: 32322397 PMCID: PMC7175902

[85] Carlucci P, Ahuja T, Petrilli CM, Rajagopalan H, Jones S, Rahimian J. Hydroxychloroquine and azithromycin plus zinc vs hydroxychloroquine and azithromycin alone: outcomes in hospitalized COVID-19 patients. medRxiv, 2020 May 8. https://doi.org/10.1101/2020.05.02.20080036

[86] Chen Z, Hu J, Zhang Z, Jiang S, Han S, Yan D, Zhuang R, Hu B, Zhang Z. Efficacy of hydroxychloroquine in patients with COVID-19: results of a randomized clinical trial. medRxiv, 2020 Apr 10. https://doi.org/10.1101/2020.03.22.20040758

[87] European Medicines Agency (EMA). COVID-19: reminder of risk of serious side effects with chloroquine and hydroxychloroquine. EMA/202483/2020 Rev, accessed: 2 May 2020. https://www.ema.europa.eu/en/documents/press-release/co vid-19-reminder-risk-serious-side-effects-chloroquine-hydroxy chloroquine_en.pdf

[88] Lane JCE, Weaver J, Kostka K, Duarte-Salles T, Abrahao MTF, Alghoul H, Alser O, Alshammari TM, Biedermann P, Burn E, Casajust $\mathrm{P}$, Conover M, Culhane AC, Davydov A, DuVall SL, Dymshyts D, Fernández Bertolín S, Fišter K, Hardin J, Hester L, 
Hripcsak G, Kent S, Khosla S, Kolovos S, Lambert CG, ver der Lei J, Lynch KE, Makadia R, Margulis AV, Matheny ME, Mehta P, Morales DR, Morgan-Stewart $\mathrm{H}$, Mosseveld $\mathrm{M}$, Newby D, Nyberg F, Ostropolets A, Park RW, Prats-Uribe A Rao GA, Reich C, Reps J, Rijnbeek P, Sathappan SMK, Schuemie M, Seager S, Sena A, Shoaibi A, Spotnitz M, Suchard MA, Swerdel J, Torre CO, Vizcaya D, Wen H, de Wilde M, You SC, Zhang L, Zhuk O, Ryan P, Prieto-Alhambra D. Safety of hydroxychloroquine, alone and in combination with azithromycin, in light of rapid wide-spread use for COVID-19: a multinational, network cohort and self-controlled case series study. medRxiv, 2020 May 31. https://doi.org/10.1101/2020. 04.08.20054551

[89] Rathi S, Ish P, Kalantri A, Kalantri S. Hydroxychloroquine prophylaxis for COVID-19 contacts in India. Lancet Infect Dis, 2020 Apr 17:S1473-3099(20)30313-3. https://doi.org/10.1016/ S1473-3099(20)30313-3 PMID: 32311324 PMCID: PMC7164849

[90] Ferreira A, Oliveira-E-Silva A, Bettencourt P. Chronic treatment with hydroxychloroquine and SARS-CoV-2 infection. J Med Virol, 2020 Jul 9:10.1002/jmv.26286. https://doi.org/10.1002/jmv. 26286 PMID: 32644224 PMCID: PMC7361589

[91] Hernandez AV, Roman YM, Pasupuleti V, Barboza JJ, White CM. Update alert: hydroxychloroquine or chloroquine for the treatment or prophylaxis of COVID-19. Ann Intern Med, 2020 173(4):W78-W79. https://doi.org/10.7326/L20-0945 PMID: 32667853 PMCID: PMC7377263

[92] Horby P, Mafham M, Linsell L, Bell JL, Staplin N, Emberson JR, Wiselka M, Ustianowski A, Elmahi E, Prudon B, Whitehouse A, Felton T, Williams J, Faccenda J, Underwood J, Baillie JK, Chappell L, Faust SN, Jaki T, Jeffery K, Lim WS, Montgomery A, Rowan K, Tarning J, Watson JA, White NJ, Juszczak E, Haynes R, Landray MJ. Effect of hydroxychloroquine in hospitalized patients with COVID-19: preliminary results from a multi-centre, randomized, controlled trial. medRxiv, 2020 Jul 15. https://doi.org/10.1101/2020.07.15.20151852

[93] Laopaiboon M, Panpanich R, Swa Mya K. Azithromycin for acute lower respiratory tract infections. Cochrane Database Syst Rev, 2015, 2015(3):CD001954. https://doi.org/10.10 02/14651858.CD001954.pub4 PMID: 25749735 PMCID: PMC6956663

[94] Lode H, Borner K, Koeppe P, Schaberg T. Azithromycin review of key chemical, pharmacokinetic and microbiological features. J Antimicrob Chemother, 1996, 37(Suppl C):1-8. https://doi.org/10.1093/jac/37.suppl_c.1 PMID: 8818841

[95] Jelić D, Antolović R. From erythromycin to azithromycin and new potential ribosome-binding antimicrobials. Antibiotics (Basel), 2016, 5(3):29. https://doi.org/10.3390/antibiotics5030029 PMID: 27598215 PMCID: PMC5039525

[96] Gielen V, Johnston SL, Edwards MR. Azithromycin induces anti-viral responses in bronchial epithelial cells. Eur Respir J, 2010, 36(3):646-654. https://doi.org/10.1183/09031936.000 95809 PMID: 20150207

[97] Tran DH, Sugamata R, Hirose T, Suzuki S, Noguchi $Y$, Sugawara A, Ito F, Yamamoto T, Kawachi S, Akagawa KS, Ōmura S, Sunazuka T, Ito N, Mimaki M, Suzuki K. Azithromycin, a 15-membered macrolide antibiotic, inhibits influenza $A(H 1 N 1)$ pdm09 virus infection by interfering with virus internalization process. J Antibiot (Tokyo), 2019, 72(10):759-768. https:// doi.org/10.1038/s41429-019-0204-x PMID: 31300721

[98] Abrams RPM, Solis J, Nath A. Therapeutic approaches for Zika virus infection of the nervous system. Neurotherapeutics, 2017, 14(4):1027-1048. https://doi.org/10.1007/s13311-017-0575-2 PMID: 28952036 PMCID: PMC5722777

[99] Bosseboeuf E, Aubry M, Nhan T, de Pina JJ, Rolain JM, Raoult D, Musso D. Azithromycin inhibits the replication of Zika virus. J Antivir Antiretrovir, 2018, 10(1):6-11. https://doi.org/ 10.4172/1948-5964.1000173

[100] Retallack H, Di Lullo E, Arias C, Knopp KA, Laurie MT, Sandoval-Espinosa C, Mancia Leon WR, Krencik R, Ullian EM Spatazza J, Pollen AA, Mandel-Brehm C, Nowakowski TJ, Kriegstein AR, DeRisi JL. Zika virus cell tropism in the developing human brain and inhibition by azithromycin. Proc Natl Acad Sci U S A, 2016, 113(50):14408-14413. https://doi.org/10.1073/pnas.1618029113 PMID: 27911847 PMCID: PMC5167169

[101] Cramer CL, Patterson A, Alchakaki A, Soubani AO. Immunomodulatory indications of azithromycin in respiratory disease: a concise review for the clinician. Postgrad Med, 2017, 129(5):493-499. https://doi.org/10.1080/00325481. 2017.1285677 PMID: 28116959

[102] Menzel M, Akbarshahi H, Bjermer L, Uller L. Azithromycin induces anti-viral effects in cultured bronchial epithelial cells from COPD patients. Sci Rep, 2016, 6:28698. https://doi.org/ 10.1038/srep28698 PMID: 27350308 PMCID: PMC4923851

[103] Porter JD, Watson J, Roberts LR, Gill SK, Groves H, Dhariwal J, Almond MH, Wong E, Walton RP, Jones LH, Tregoning J, Kilty I, Johnston SL, Edwards MR. Identification of novel macrolides with antibacterial, anti-inflammatory and type I and III IFN-augmenting activity in airway epithelium. J Antimicrob Chemother, 2016, 71(10):2767-2781. https:// doi.org/10.1093/jac/dkw222 PMID: 27494903 PMCID: PMC5031920

[104] Taylor SP, Sellers E, Taylor BT. Azithromycin for the prevention of COPD exacerbations: the good, bad, and ugly. Am J Med, 2015, 28(12):1362.e1-1362.e6. https://doi.org/ 10.1016/j.amjmed.2015.07.032 PMID: 26291905

[105] Chico RM, Chandramohan D. Azithromycin plus chloroquine: combination therapy for protection against malaria and sexually transmitted infections in pregnancy. Expert Opin Drug Metab Toxicol, 2011, 7(9):1153-1167. https://doi.org/ 10.1517/17425255.2011.598506 PMID: 21736423 PMCID: PMC3170143

[106] Luke DR, Foulds G. Disposition of oral azithromycin in humans. Clin Pharmacol Ther, 1997, 61(6):641-648. https:// doi.org/10.1016/S0009-9236(97)90098-9 PMID: 9209246

[107] Andreani J, Le Bideau M, Duflot I, Jardot P, Rolland C, Boxberger M, Wurtz N, Rolain JM, Colson P, La Scola B, Raoult $\mathrm{D}$. In vitro testing of combined hydroxychloroquine and azithromycin on SARS-CoV-2 shows synergistic effect. Microb Pathog, 2020, 145:104228. https://doi.org/ 10.1016/j.micpath.2020.104228 PMID: 32344177 PMCID: PMC7182748

[108] Bleyzac N, Goutelle S, Bourguignon L, Tod M. Azithromycin for COVID-19: more than just an antimicrobial? Clin Drug Investig, 2020, 40(8):683-686. https://doi.org/10.1007/s40 261-020-00933-3 PMID: 32533455 PMCID: PMC7290142

[109] Arshad S, Kilgore P, Chaudhry ZS, Jacobsen G, Wang DD, Huitsing K, Brar I, Alangaden GJ, Ramesh MS, McKinnon JE, O'Neill W, Zervos M; Henry Ford COVID-19 Task Force. Treatment with hydroxychloroquine, azithromycin, and combination in patients hospitalized with COVID-19. Int $\mathrm{J}$ Infect Dis, 2020, 97:396-403. https://doi.org/10.1016/j.ijid. 2020.06.099 PMID: 32623082 PMCID: PMC7330574

[110] Lighter J, Raabe V. Azithromycin should not be used to treat COVID-19. Open Forum Infect Dis, 2020, 7(6):ofaa207. https://doi.org/10.1093/ofid/ofaa207 PMID: 32550240 PMCID: PMC7291686

[111] Juurlink DN. Safety considerations with chloroquine, hydroxychloroquine and azithromycin in the management of SARSCoV-2 infection. CMAJ, 2020, 192(17):E450-E453. https:// doi.org/10.1503/cmaj.200528 PMID: 32269021 PMCID: PMC7207200

[112] Garg A, Garg S, Zaneveld LJ, Singla AK. Chemistry and pharmacology of the Citrus bioflavonoid hesperidin. Phytother Res, 2001, 15(8):655-669. https://doi.org/10.1002/ptr.1074 PMID: 11746857

[113] Gattuso G, Barreca D, Gargiulli C, Leuzzi U, Caristi C. Flavonoid composition of Citrus juices. Molecules, 2007, 12(8):1641-1673. https://doi.org/10.3390/12081641 PMID: 17960080 PMCID: PMC6149096

[114] Morand C, Dubray C, Milenkovic D, Lioger D, Martin JF, Scalbert A, Mazur A. Hesperidin contributes to the vascular protective effects of orange juice: a randomized crossover study in healthy volunteers. Am J Clin Nutr, 2011, 93(1):7380. https://doi.org/10.3945/ajcn.110.004945 PMID: 21068346

[115] Pla-Pagà L, Companys J, Calderón-Pérez L, Llauradó E, Solà R, Valls RM, Pedret A. Effects of hesperidin consumption on cardiovascular risk biomarkers: a systematic review of animal studies and human randomized clinical trials. Nutr Rev, 2019, 77(12):845-864. https://doi.org/10.1093/nutrit/ nuz036 PMID: 31271436

[116] Aptekmann NP, Cesar TB. Long-term orange juice consumption is associated with low LDL-cholesterol and apolipoprotein B in normal and moderately hypercholesterolemic subjects. Lipids Health Dis, 2013, 12:119. https:// 
doi.org/10.1186/1476-511X-12-119 PMID: 23919812 PMCID: PMC3750609

[117] Mahmoud AM, Hernández Bautista RJ, Sandhu MA, Hussein OE. Beneficial effects of Citrus flavonoids on cardiovascular and metabolic health. Oxid Med Cell Longev, 2019, 2019:5484138. https://doi.org/10.1155/2019/5484138 PMID: 30962863 PMCID: PMC6431442

[118] Tejada S, Pinya S, Martorell M, Capó X, Tur JA, Pons A, Sureda A. Potential anti-inflammatory effects of hesperidin from the genus Citrus. Curr Med Chem, 2018, 25(37): 4929-4945. https://doi.org/10.2174/0929867324666170718 104412 PMID: 28721824

[119] Wilmsen PK, Spada DS, Salvador M. Antioxidant activity of the flavonoid hesperidin in chemical and biological systems. J Agric Food Chem, 2005, 53(12):4757-4761. https://doi.org/10.1021/jf0502000 PMID: 15941311

[120] Ganeshpurkar A, Saluja A. The pharmacological potential of hesperidin. Indian J Biochem Biophys, 2019, 56(4):287300. http://op.niscair.res.in/index.php//JBB/article/view/27358

[121] Li Y, Kandhare AD, Mukherjee AA, Bodhankar SL. Acute and sub-chronic oral toxicity studies of hesperidin isolated from orange peel extract in Sprague Dawley rats. Regul Toxicol Pharmacol, 2019, 105:77-85. https://doi.org/10.10 16/j.yrtph.2019.04.001 PMID: 30991075

[122] Utomo RY, Ikawati M, Meiyanto E. Revealing the potency of Citrus and galangal constituents to halt SARS-CoV-2 infection. Preprints, 2020 Mar 12:2020030214. https://doi.org/ 10.20944/preprints202003.0214.v1

[123] Ding Z, Sun G, Zhu Z. Hesperidin attenuates influenza A virus (H1N1) induced lung injury in rats through its antiinflammatory effect. Antivir Ther, 2018, 23(7):611-615. https://doi.org/10.3851/IMP3235 PMID: 29623897

[124] Saha RK, Takahashi T, Suzuki T. Glucosyl hesperidin prevents influenza $A$ virus replication in vitro by inhibition of viral sialidase. Biol Pharm Bull, 2009, 32(7):1188-1192. https://doi.org/10.1248/bpb.32.1188 PMID: 19571383

[125] Adem S, Eyupoglu V, Sarfraz I, Rasul A, Ali M. Identification of potent COVID-19 main protease $\left(\mathrm{M}^{\text {pro }}\right)$ inhibitors from natural polyphenols: an in silico strategy unveils a hope against CORONA. Preprints, 2020 Mar 23:2020030333. https://doi.org/10.20944/preprints202003.0333.v1

[126] Cheng L, Zheng W, Li M, Huang J, Bao S, Xu Q, Ma Z. Citrus fruits are rich in flavonoids for immunoregulation and potential targeting ACE2. Preprints, 2020 Feb 23:2020020313. https:// www.preprints.org/manuscript/202002.0313/v1

[127] Meneguzzo F, Ciriminna R, Zabini F, Pagliaro M. Review of evidence available on hesperidin-rich products as potential tools against COVID-19 and hydrodynamic cavitation-based extraction as a method of increasing their production. Processes, 2020, 8(5):549. https://doi.org/10.3390/pr8050 549

[128] Plescia J, Moitessier N. Design and discovery of boronic acid drugs. Eur J Med Chem, 2020, 195:112270. https:// doi.org/10.1016/j.ejmech.2020.112270 PMID: 32302879

[129] Srivastava AK, Singh D. Destabilizing the structural integrity of SARS-CoV2 receptor proteins by curcumin along with hydroxychloroquine: an in silico approach for a combination therapy. ChemRxiv, 2020 Apr 10. https://doi.org/10.26434/ chemrxiv.12090438.v1

[130] Mohan TC, Jones AME. Determination of boron content using a simple and rapid miniaturized curcumin assay. Bio Protoc, 2018, 8(2):e2703. https://doi.org/10.21769/Bio Protoc.2703 PMID: 29430483 PMCID: PMC5802381

[131] Slabber CA, Grimmer CD, Robinson RS. Solution conformations of curcumin in DMSO. J Nat Prod, 2016, 79(10): 2726-2730. https://doi.org/10.1021/acs.jnatprod.6b00726 PMID: 27715050

[132] Bellamy LJ, Spicer GS, Strickland JDH. Compounds of curcumin and boric acid. Part III. Infra-red studies of rosocyanin and allied compounds. J Chem Soc, 1952, Article 908:4653-4656. https://doi.org/10.1039/JR952000 4653

[133] John J, Rugmini SD, Nair BS. Kinetics and mechanism of the thermal and hydrolytic decomposition reaction of rosocyanin. Int J Chem Kinet, 2018, 50(3):164-177. https://doi.org/10. 1002/kin.21148

[134] Wanninger S, Lorenz V, Subhan A, Edelmann FT. Metal complexes of curcumin - synthetic strategies, structures and medicinal applications. Chem Soc Rev, 2015, 44(15): 4986-5002. https://doi.org/10.1039/c5cs00088b PMID: 25964104

[135] Kim JY, Kang YY, Kim EJ, Ahn JH, Mok H. Effects of curcumin-/boron-based compound complexation on antioxidant and antiproliferation activity. Appl Biol Chem, 2018, 61(4):403-408. https://doi.org/10.1007/s13765-018-0374-4

[136] Khaerunnisa S, Kurniawan H, Awaluddin R, Suhartati S, Soetjipto S. Potential inhibitor of COVID-19 main protease $\left(\mathrm{M}^{\mathrm{pro}}\right)$ from several medicinal plant compounds by molecular docking study. Preprints, 2020 Mar 13:2020030226. https:// doi.org/10.20944/preprints202003.0226.v1

[137] Vega-Valdez IR, Santiago-Quintana JM, Rosalez MN, FarfánGarcía ED, Soriano-Ursúa MA. Theoretical evaluation of bortezomib and other boron-containing compounds as inhibitors of SARS-CoV-2 main protease. ChemRxiv, 2020 Mar 31. https://doi.org/10.26434/chemrxiv.12047346.v1

\section{Corresponding author}

Ion Romulus Scorei, Professor, Biochem, PhD, BioBoron Research Institute, S.C. Natural Research S.R.L., 31B Dunării Street, 207465 Podari, Dolj County, Romania; Phone +40351-407 543, e-mail: romulus_ion@yahoo.com

Received: April 8, 2020

Accepted: September 25, 2020 